NBER WORKING PAPER SERIES

\title{
PROPERTY RIGHTS AND URBAN FORM
}

\author{
Simeon Djankov \\ Edward L. Glaeser \\ Valeria Perotti \\ Andrei Shleifer \\ Working Paper 28793 \\ http://www.nber.org/papers/w28793 \\ NATIONAL BUREAU OF ECONOMIC RESEARCH \\ 1050 Massachusetts Avenue \\ Cambridge, MA 02138 \\ May 2021
}

We are deeply grateful to Lawrence Jia and Eva (Yiwen) Zhang for outstanding assistance with this research, and to Elodie Bataille, Marie Lily Delion, Egor Gornostay, Gary Hufbauer, Spencer Kwon, Nick Lore-Edwards, Robbie Minton, Rita Ramalho, Judith Trasancos, and Aigerim Zhanibekova for helpful comments. The findings, interpretations, and conclusions expressed in this paper are entirely those of the authors. They do not necessarily represent the views of the World Bank and its affiliated organizations, or those of the Executive Directors of the World Bank the governments they represent, or the National Bureau of Economic Research.

NBER working papers are circulated for discussion and comment purposes. They have not been peer-reviewed or been subject to the review by the NBER Board of Directors that accompanies official NBER publications.

(C) 2021 by Simeon Djankov, Edward L. Glaeser, Valeria Perotti, and Andrei Shleifer. All rights reserved. Short sections of text, not to exceed two paragraphs, may be quoted without explicit permission provided that full credit, including $\odot$ notice, is given to the source. 
Property Rights and Urban Form

Simeon Djankov, Edward L. Glaeser, Valeria Perotti, and Andrei Shleifer

NBER Working Paper No. 28793

May 2021

JEL No. K11,P14,R30

\begin{abstract}
$\underline{\text { ABSTRACT }}$
How do the different elements in the standard bundle of property rights, including those of possession and transfer, influence the shape of cities? This paper incorporates insecure property rights into a standard model of urban land prices and density, and makes predictions about investment in land and property, informality, and the efficiency of land use. Our empirical analysis links data on institutions for land titling and transfer with multiple urban outcomes, in 190 countries. The evidence is generally consistent with the model's predictions, and more broadly with the Demsetz's (1967) approach to property rights institutions. Indeed, we document world-wide improvements in the quality of institutions facilitating property transfer over time.
\end{abstract}

Simeon Djankov

London School of Economics

and Political Science

Houghton Street

London WC2A 2AE

United Kingdom

s.djankov@1se.ac.uk

Edward L. Glaeser

Department of Economics

315A Littauer Center

Harvard University

Cambridge, MA 02138

and NBER

eglaeser@harvard.edu

\author{
Valeria Perotti \\ The World Bank Group \\ 1818 H Street NW \\ Washington, DC 20433 \\ vperotti@worldbank.org \\ Andrei Shleifer \\ Department of Economics \\ Harvard University \\ Littauer Center M-9 \\ Cambridge, MA 02138 \\ and NBER \\ ashleifer@harvard.edu
}




\section{Introduction}

Ownership can confer a bundle of property rights, including the right to possess, to transfer, and to alter (Ellickson 1993, Alchian 2008). ${ }^{2}$ As stressed in the pioneering work of Demsetz (1967), the protection of any of these rights is never free, and varies greatly across jurisdictions. In the developing world, many of these rights are quite ephemeral, as possession is not guaranteed, sale is difficult, and alteration is highly regulated. Still, in a world of limited public capacity, one can ask: which rules and institutions matter for economic activity, and how? In this paper, we address this question empirically using a crosssection of 190 countries, and focus specifically on the consequences of the right of possession and the right of transfer in the context of urban land.

The most basic element in this Blackstonian bundle of property rights is possession - the right to exclude others from taking or invading the property. This right is typically secured by the government, but occasionally by other means, such as self-defense. The state, of course, can also be the taker or invader of property. Writers including Montesquieu (1748), Smith (1776), Olson (1965), North (1981), Barro (1990), DeLong and Shleifer (1993), and Acemoglu et al. (2001) recognized entitlement to the undisturbed use of one's property as essential for protecting investment and economic development. In the context of urban development, the right of possession is central to the quality of the housing stock. When title is insecure, residents invest less in land and housing, and urban density rises.

The right to transfer was less central to classical economists than the logically prior right of possession, but more recent authors have stressed how transfer can enable property to be sold or

\footnotetext{
${ }^{2}$ The right to transfer includes the right to rent (temporary transfer) and the right to mortgage (conditional transfer). Ellickson (1993) describes a complete "Blackstonian" bundle of property rights, which include the right to "exclude," in the sense that we use possession, and "use and abuse," which to us is synonymous with alter. He defines transfers more thoroughly, but we intend our meaning to be the same. Ellickson also specifies the time frame of ownership (perpetual), its physical boundaries (limited in two dimensions, but stretching "downward to the depths of the earth and upward to the heavens"), and resting in a single proprietor.
} 
rented to more efficient users or owners with access to capital (Barzel 1982, Ellickson 1993, Alchian 2008). DeSoto (2000) stresses the role of urban land as potential collateral for entrepreneurs, and mortgages hinge on the conditional transfer of land in case of default. The right of transfer is logically secondary to the right of possession, but both may shape aspects of the urban form.

In a modern society, the protection of property rights, including both possession and transfer, is typically delivered not only by courts and police, but also by administrative institutions, such as deed registration offices. Empirically, much attention has been devoted to the effectiveness of courts and regulators in protecting private property, including in cross-country contexts (e.g., Djankov et al. 2003, La Porta et al. 2004, Behrer et al. 2021). Less is known about the role of administrative institutions that keep track of ownership and its transfer.

Title is the central legal instrument that both secures possession and enables the transfer of property. Documenting formal title is usually a prerequisite for using legal authority to protect one's land and dwellings, and that is done through administrative tools, such as cadasters and deeds. Without formal title, residents must rely on self-protection to assure unhindered enjoyment of their residence and land (Field 2005, 2007), and have a limited incentive to invest in such informally owned property (De Soto 1989, Besley 1995). Only secure title can in principle provide protection against expropriation by armed bandits, powerful neighbors, and the grabbing hand of the state (Olson 1993, Shleifer and Vishny 1998, De Soto 2000, Behrer et al., 2021).

The institutions that track and enable the transfer of title ensure the legal recognition and sanction of the permanent transfer of property ownership. ${ }^{3}$ In many of the world's informal urban communities, residents are relatively safe against expropriation and eviction, but without legal sale they

\footnotetext{
${ }^{3}$ We do not focus on the temporary transfer of property through rental arrangements, for these are typically limited more by rent control rules than by title. Glaeser and Luttmer (2003) empirically quantify the misallocation of apartments due to rent control.
} 
lack the means to trade their property for cash, move closer to work, or borrow money through a mortgage (De Soto 2000). Even with title, the time and money cost of a legal sale may stymie mobility and leave residents rooted in place. That stasis may explain the long commutes between informal communities and formal work in many developing world cities, like Kigali (Collier and Venables 2014). ${ }^{4}$

In this paper, we investigate the distinction between the right of possession and the right of transfer, and the distinctive effects that the institutions protecting these rights have on the urban form. To this end, we analyze a large cross-country data set assembled by the World Bank over the last 16 years. The data set contains information on institutions securing property title, as well as the institutions governing the transfer of ownership, for 190 countries.

We seek to accomplish three goals. First, we describe the relevant data sets, and show how property rights institutions covering both the titling of property and its transfer can be objectively measured. Second, we present new evidence that these institutions have a substantial impact on economic outcomes, especially in the context of the allocation of urban land. Third, we present some evidence that, unlike many institutions that previous research has shown to be sticky, the institutions we describe here show dramatic improvement over the 16 years of the data.

Our first goal is to describe the institutions of titling and transferring property from the DB database. A large literature uses measures of security of property rights obtained in surveys of investors, experts, and households. La Porta et al. (1999) provide a summary of many of these measures; Chong et al. (2014) present related findings from the World Justice Project (WJP) database. These survey measures are outputs of a system of securing property rights, and hence are extremely highly correlated with multiple inputs including not just legal and regulatory rules and infrastructure but also human

\footnotetext{
${ }^{4} \mathrm{~A}$ third element of the property rights bundle, which we do not focus on here, is the right to develop or improve one's land and property, which is often restricted by zoning.
} 
capital. Here instead we use administrative rules governing titling and transfer of property, and analyze their impact holding constant the level of human capital. A further advantage of measuring specific rules rather than survey outcomes is that rules are subject to modification, reform, and improvement over horizons shorter than the general growth of public sector capacity and human capital.

The database contains two types of variables. First, it contains data on the titling process, including the reliability of title infrastructure, the transparency of title information, the geographic coverage of titling, and the mechanisms of resolving title disputes. These indicators are aggregated into a Title index, which describes the quality of legal and regulatory infrastructure that administers the titling process. Second, the database contains - over a period of 16 years - data on rules governing the transfer of urban property, including the number of steps it takes to transfer a piece of property, the cost of doing so, and the time it takes in a typical case. We aggregate these indicators into a Transfer index. In Section 2, we describe how these data are constructed both from hard information on rules and procedures, and from surveys of professionals involved in the titling and the transfer of property.

We also establish three preliminary findings. First, there is tremendous disparity in the quality of institutions of titling and transferring property across countries, but they are generally much better in more developed (or higher human capital) countries. The finding is not surprising, since human capital of a country and its level of economic development are typically closely associated with all measures of government effectiveness (see La Porta et al. 1999, Glaeser et al. 2004). Second, perhaps more surprisingly, although the data on titling and transfer institutions are collected in very different ways, there is a high correlation between the quality of the two types of institutions, even controlling for the level of economic development. And third, several of the determinants of the quality of institutions identified in previous research, such as human capital, the level of development, and government effectiveness, matter here as well, while others, such as legal origin, do not. 
In Section 3, we present a theoretical model of a city using the Alonso-Muth-Mills framework (Brueckner, 1987) in which formal jobs are located in city center, while residents live and work informally if they do not have formal jobs, away from the center. The model allows one to study the size of the city, its residential density, commute times, and patterns of land ownership. We add to this standard framework a cost of protecting one's property, as well as limitations on property transfer.

These alterations to the standard model yield several predictions, but we focus on two. First, limitations on the right of possession lead to reduced consumption of urban land. Residents must either invest in self-protection or risk losing their property, and both the costs and the risk scale up with investment. Consequently, residents invest less, consume lower quality housing, and urban density levels are higher. Second, limits on the right to transfer imply that people remain stuck in place even if they have to commute to work far from home, leading to greater traffic congestion. In Section 4, we test these key predictions of our model that weak possession rights lead to high density and poor structures and that weak transfer rights lead to a spatial mismatch between residences and workplaces. We use urban data on density, slum presence, and traffic congestion to evaluate our hypotheses.

For our housing structure and density outcomes, we use the percentage of urban population living in slums (which are typically informal), residential density, and the average size of formal and informal plot sizes. We use four aspects of titling quality to measure right of possession, as well as the Title index aggregating them. We typically control for the logarithm of per capita gross domestic product. Three of the four measures and the overall Title index all show that better right of possession is associated with a smaller share of residents living in slums. The Title index is also significantly negatively correlated with density and positively associated with informal lot size. Transfer rights are not correlated with any of these outcomes, just as the model predicts. 
We then test whether weak transfer rights are associated with more traffic congestion and we find that to be the case as well. Housing always has two critical qualities: location and physical structure. The model predicts that the right of possession is associated with better structure and that right of transfer is associated with better location. Both predictions find support in the data.

Finally, we examine the prevalence of home-related lending across countries, which should be influenced by both title and transfer institutions. A mortgage loan relies both on a valid title, and on the ability to repossess and sell (transfer) the property if the borrower defaults. While both title and transfer measures correlate with the prevalence of mortgages, the number of transfer procedures influences the penetration of housing loans, even controlling for both title and the per capita income. This result shows the key role of the right of transfer for financial development.

In Section 5, we describe the evolution of institutions governing property transfer over the relatively short period of our sample. We have the transfer variables over 16 years, but we only have the title variables for a few years. For many institutions, particularly those tied to legal traditions of countries, the data show a great deal of persistence (La Porta, Lopez de Silanes, and Shleifer 2008), but here we find something different. Over a 16-year period, many countries sharply improved their institutions for transferring property. The timeframe is too short to allow us to test whether these institutional changes translate to reduced commute lengths, or other improvements in urban form.

The mechanisms behind such improvement largely result from the pervasive introduction of information technology. We found little evidence that suggested that these changes were politicallymotivated, but rather that they were efficiency driven. As cities grow, it becomes increasingly efficient to invest in better procedures for formalizing the transfer of property. Many cities have accommodated that demand. As Demsetz (1967) argued over half a century ago, the creation and improvement of property rights institutions follows, at least in part, the needs of economic efficiency. 


\section{Data and Initial Findings}

We build two sets of variables pertaining to the measurement of property rights, using data from the World Bank: a Title index comprising four subindices of the Quality of Land Administration index; and a Transfer index of three variables on the number of procedures, time and cost of transferring property title between private parties (Table 1). These indices are constructed by unpacking the World Bank's Registering Property Score, which consists (with equal weighting) of Transfer Procedures, Transfer Time, Transfer Cost, and the Quality of Land Administration index.

The World Bank collected the data by reviewing the relevant laws and regulations, and using surveys filled out by property lawyers, notaries, and administrators in land and cadastral registries. Data are collected for the main business city in 190 economies. The data collection process is described in greater detail on the World Bank webpage; Online Appendix A describes the variable construction procedures, including our institutional measures, in detail.

\section{Title}

In addition to police protection, several administrative processes make the title more secure. First, authorities can make transparent and easily accessible all the information pertaining to encumbrances on the property in question. Second, they can make this access universal: for any property and from anywhere. And third, they can establish a straightforward resolution process should challenges to the title arise. This resolution process can be court supervised or part of the administrative protection of title. Different countries approach the security of title differently. While France makes geographic access universal, Australia does not. While the United Kingdom has an expedient resolution process, Greece has a lengthy process to challenge title infringements. 
The World Bank's Quality of Land Administration index measures the security of title. It is comprised of five subindices: reliability of title infrastructure, transparency of title information, geographic coverage of titling, title dispute resolution, and gender equality in rights to title. The gender equality subindex is not used separately in this study as it shows very limited variation across the sample. We use the remaining four equally-weighted indices to construct a Title index. Data for the Title index are available for five years, 2015 to 2019. We use 2015 in the analysis.

The first subindex for the Title index, reliability of title infrastructure, captures the consistency and dependability of recordkeeping systems in a country's property management system. This subindex records whether title and cadastral records are electronic, stored in a reliable database, and are consistently maintained between governmental agencies. This index ranges from 0 to 8 . In Turkey, for example, titles and cadastral maps are fully electronic and databases about land ownership are linked. Turkey receives a perfect score of 8 on the subindex. Oman, where land title certificates are kept in paper format at the immovable property registry, receives a 5 while Afghanistan, with paper-based and separate databases at the immovable property registry and the cadastral agency, receives a 0.

The second subindex for the Title index, transparency of information, captures the availability of property information to the general public. This subindex records whether cadastral plans, fee schedules, required documents, and complaint systems are made easily available to the public. This index ranges from 0 to 6 . In the Netherlands, for example, an online title database, a required document list, a fee schedule, and a complaint mechanism are all available using the Kadaster website, which gives it a perfect score of 6 . Montenegro, with neither public statistics about transactions nor an independent complaint mechanism, receives a 3; Sudan, where only intermediaries and interested parties can obtain title information - and fee schedules are only available in person - receives a 0. 
The third subindex for the Title index, geographic coverage of titling information, captures the completeness of information at the land registry and mapping agency. This subindex ranges from 0 to 8 . For instance, in the Republic of Korea, all land plots are registered and mapped at the local and national level, giving Korea a perfect score of 8. Portugal, where all land plots are formally registered or mapped, but only at the local level, receives a 4, while Senegal, where land is not fully registered or mapped even in the main business city, receives a 0 .

The fourth subindex for the Title index, dispute resolution, captures the effectiveness and efficiency of the legal system regarding property disputes. The subindex records whether there are formal compensation mechanisms, legal verification and guarantee systems, fair legal rules, and efficient court systems. The title dispute resolution subindex ranges from 0 to 8 . In the United Kingdom, all property sales are guaranteed by government, lawyers are required to verify legal documents with a national database, and the court system rules quickly, giving it a perfect score of 8 . Peru, where there is no out-of-court compensation mechanism and a land dispute can take 2 to 3 years to resolve, receives a 5 on the subindex, while Sri Lanka, where there are no guarantees on property registration and no databases for verifying identity documents, receives a 1.

\section{Transfer of Title}

The World Bank database contains three Transfer variables measuring this process in the country's largest business city. These include the number of procedures, the time, and the cost to purchase and transfer a property title from a private seller to a private buyer. Transferring title begins with obtaining necessary documents, such as a copy of the seller's title, and is considered complete when the buyer can use the newly-acquired property. Every procedure required by law or necessary in practice is included, whether it is the responsibility of the seller or the buyer or a third party on their 
behalf. Data for the Transfer variables are available for 16 years, from 2004 to 2019, and we use 2013 data for the analysis here.

Several assumptions are made for comparability across countries. These assumptions also simplify the case, as they take away the most likely ways in which the transfer of title can be complicated. The buyer and the seller are assumed to be limited liability companies, located in the periurban area of the economy's largest business city, $100 \%$ domestically and privately owned, and to perform general commercial activities. The property is assumed to have a value 50 times per capita income, be fully owned by the seller for the past 10 years with no mortgage, registered in the land registry, free of title disputes, located in a peri-urban commercial zone, not be subject to renovations after purchase, be used for general commercial purpose, have no occupants, and have no other party with a legal interest in it.

The Transfer Procedures variable captures the interactions between the buyer, the seller, or their agents with external parties, including government agencies, inspectors, notaries, and surveyors. The fastest legal procedure required for transferring title is measured when more than one procedure exists. There is significant difference in how many procedures are required by law to transfer title. For example, a transfer of title in Managua, Nicaragua in 2013 legally required 9 separate procedures whereas it required 5 separate procedures in Riga, Latvia and 2 in Manama, Bahrain.

The Transfer Time variable captures, in days, the median duration that property lawyers, notaries, or registry officials indicate is necessary to complete a title transfer. The fastest legal procedure required for transferring title is recorded. For instance, a transfer of property in Port-auPrince, Haiti in 2013 required 319 days to complete whereas it required only 4 days in Toronto, Canada.

The Transfer Cost variable captures the official costs required by law as a percentage of the property value (assumed to be 50 times income per capita). These costs include fees, transfer taxes, 
stamp duties, and other payments to the title registry, notaries, public agencies or lawyers. For instance, a transfer of title in Douala, Cameroon in 2013 cost 19.1\% of the property value, whereas in Quito, Ecuador it cost $1.9 \%$ of the property value.

We construct an overall Transfer index as the sum of the z-scores of the procedures, time, and cost variables. The higher the value of the index, the less efficient is the transfer of title.

\section{Outcome Data}

The United Nations Human Settlement Programme (UN Habitat) provides the number of people living in slums as a percentage of the urban population for 83 economies in our sample. For instance, in $2018,38 \%$ of the urban population in the Philippines and $23 \%$ of the urban population in South Africa lived in slums.

The Lincoln Land Institute's Atlas of Urban Expansion provides data on cross-country land outcomes using satellite imagery and is comprised of two sets: 1) Blocks and Roads and 2) Areas and Densities. These data are available for up to 76 economies in our sample. First, the Blocks and Roads dataset measures the configuration of cities. Image analysts divided individual city blocks into "plots", or individual parcels of land that would likely be identified as separate properties in a cadaster. The dataset distinguishes between informal land subdivisions and formal land subdivisions. Informal land subdivisions are areas that are "subdivided for urban use but lack visible conformity to land subdivision regulations such as regular plot dimensions, paved roads, or sidewalks." Formal land subdivisions are "similar in layout to informal layouts, but exhibit a higher level of regularity, a higher level of provision of infrastructure, and better connections to existing roads."

Variables in this dataset include measures of average plot size in formal and informal land subdivisions. For instance, the average plot size in formal and informal land divisions in El Salvador were 
157 and 77 square meters respectively in 2015. These variables are constructed from satellite imagery for areas developed between the years 1990 and 2015.

The Areas and Densities dataset measures compactness of the urban area. Each pixel of satellite images was classified as built-up areas (human-constructed, impervious surfaces), open space, or water. The built-up area density variable was then calculated by taking total population of the city and dividing by its built-up area. For example, the built-up area density in El Salvador was 100 people per hectare. These data are available for years 1990, 2000, and circa 2013. We use values from circa 2013.

TomTom's public database measures city-level traffic congestion in 56 economies covered in our data. The index uses real traffic data from 600 million drivers to calculate the excess travel time during rush hour as a percentage of off-peak travel time. In 2019, an average trip during rush hour took $18 \%$ more time than in baseline traffic in Iceland, but $60 \%$ longer in India.

Finally, the percentage of adult population with an outstanding loan to purchase a home, obtained from the World Bank's Global Findex database, is used as a measure of housing loan penetration. We use the data for 2017.

\section{Control variables}

The World Development Indicators contain annual per capita GDP which we use as a control for 185 economies. The World Governance Indicators project provides an index on government effectiveness, capturing perceptions on quality of public services and quality of civil services for 189 economies. The indicator ranges from -2.5 (weak governance) to 2.5 (strong governance). The World Bank's Human Capital index is constructed from measures of child survival rates, expected years of school, and childhood health factors and is available for 168 economies. The index ranges from 0 (low human capital) to 1 (high human capital). 


\section{Preliminary Findings}

The Title index is highly variable, with a mean of 14.26 in our sample of countries, and a standard deviation of 7.49. As a first step, we check whether this index is correlated with a closely related survey measure of the quality of property rights protection from the WJP database, namely a measure of the risk of expropriation of property by the government without due compensation. Figure 1 shows the correlation between Title and the WJP expropriation risk. Of course, Title generally has higher values in more developed countries. When we split the sample into quintiles by per capita income, countries in the top quintile score nearly three times higher than countries in the bottom quintile (Figure 2). Table 2 presents these results more formally, using continuous measures. We regress Title and the four subindices, as well as the four transfer variables including the Transfer index, separately on per capita income, human capital, and government effectiveness. We uniformly find positive and significant correlations. This result is not surprising since the quality of government institutions across the board rises with human capital (La Porta et al. 1999, Chong et al. 2014). ${ }^{5}$

There is a strong correlation between the Title index and subindices and the Transfer variables. This is somewhat surprising because the Title index is created with a different methodology than the Transfer variables (procedures, time, cost). Even when controlling for per capita income, the partial correlation between Title and Transfer is -.493 (Table 3 and Figure 3). This result suggests that the security of title is associated with the efficiency of title transfer, and we should be careful in disentangling the effects of the two sets of rules and institutions.

\footnotetext{
${ }^{5}$ We have looked at several other determinants of the quality of government from previous research, such as legal origins and ethnic fractionalization, but did not find consistent results.
} 


\section{A Model of Urban Land Allocation}

We consider a simple Alonso-Muth-Mills model (Brueckner, 1987). A mass M of consumers/residents locate along a line. A fraction of consumers " $q$ " works in the city center, denoted by 0 , and the remainder work from home. We can think of city center employment as formal, and employment at home as informal. All individuals earn incomes of $W$ in the city center, but only $\delta W$ working from home, where $\delta$ is sufficiently low that anyone who has an opportunity to work in the city center will do so. Individuals who work in the center pay commuting costs of $t$ times $d$, where $d$ is the distance of daily commute. The only housing consumed is land, and utility is given by $\alpha \ln (L)+C$, where $L$ represents land and $\mathrm{C}$ reflects consumption of a composite commodity with a price normalized to one. $\mathrm{A}$ consumer's Income minus Commuting Costs must be equal to the sum of consumption $C$ and rent, so absent any expenditure on protecting one's property, $W-t d=C+p(i) L$, where $\mathrm{p}(i)$ represents the rent on land at location $i$. Those who work from home have an arbitrarily small preference to be closer to the city center, which ensures that they live on the urban edge instead of the middle of countryside. Land has a rental value of $r_{A}$ when it is not occupied by city residents.

We assume that the density of land is one at every location, and that in the urbanized areas all of that land is used by residents. In the land market equilibrium, land supply equals land demand. This means that for any segment of the line of length " $s$ ", the total supply of land " $s$ " must equal the number of consumers who live along that land times the average land demanded by each of them. If we denote by $D(i)$ the density of consumers living at location " $i$ " and by $L(i)$ as the land demanded by the average consumer at that location, then for any two locations $\mathrm{x}$ and $\mathrm{y}$, where $\mathrm{x}>\mathrm{y}, x-y=\int_{i=y}^{x} L(i) D(i) d i$.

The optimization decisions of consumers in this model deliver two choices that shape the city. Consumers must choose their location optimally, which implies $p^{\prime}(i) L(i)=-t$, for $i>0$, because commuting costs rise with distance from the city center and must be exactly offset by declining rents. 
Consumers must also choose their land consumption optimally, which implies $p(i)=\alpha / L(i)$, so rent times land consumption is constant. The last equation is a product of our functional form (which the spatial optimization equation is not), but land consumption always increases as rents fall, because in a spatial equilibrium rent declines are compensated changes.

We next introduce insecure title into this standard model. To do so, we assume that the after the property is bought or rented, it must be protected from expropriation or invasion. For simplicity, we assume that the cost of protecting one's land is " $\mathrm{k}$ " times its value. We also assume that both commuters and people working from home must pay this cost, so we do not model the Field (2005) effect of families staying at home and not going to work or school in order to protect it.

We are particularly interested in the link between security of title and urban density and land rents, and in how security of title differs from the ease of transferring title. In Proposition 1 we focus entirely on the security of title. Comparing these results with Proposition 2, which focuses on the cost of transfer, shows how the title and its transfer exert different impacts of urban form. Proposition 1 describes an equilibrium where individuals buy and consume land after they know their workplace location, and have imperfect security of tenure (all proofs are collected in the Online Appendix B).

Proposition 1 (Insecurity of Title): If $|i|<\frac{\alpha}{t} \ln \left(1+\frac{q M t}{2(1+k) r_{A}}\right)$, then rent equals $p(i)=$ $e^{-\frac{t}{\alpha}|i|}\left(\frac{q M t}{2(1+k)}+r_{A}\right)$ and density is given by $e^{-\frac{t}{\alpha}|i|}\left(\frac{q M t}{2 \alpha}+\frac{(1+k) r_{A}}{\alpha}\right)$. If $\frac{\alpha}{t} \ln \left(1+\frac{q M t}{2(1+k) r_{A}}\right)+\frac{\alpha(1-q) M}{2 r_{A}(1+k)}>$ $|i|>\frac{\alpha}{t} \ln \left(1+\frac{q M t}{2(1+k) r_{A}}\right)$, then rent equals $r_{A}$ and density is given by $(1+k) r_{A} / \alpha$. Over the entire city, density equals $\frac{2 \alpha}{t M} \ln \left(1+\frac{q M t}{2(1+k) r_{A}}\right)+\frac{\alpha(1-q)}{r_{A}(1+k)}$, which is declining with $\mathrm{k}$, and the average commute distance equals $\frac{\alpha q}{t}-\frac{2 r_{A}(1+k) \alpha}{t^{2} M} \ln \left(1+\frac{q M t}{2 r_{A}(1+k)}\right)$, which is also declining with $\mathrm{k}$. 
Proposition 1 pairs the most canonical of all urban models with the need to protect one's property. The split of the population into commuters and non-commuters leads to a two-sector urban model. Land close to the city center is occupied by commuters, who live at particularly high density levels close to formal work and pay proportionately higher rents. Rents decline exponentially with distance from the city and density falls alongside the rent.

Insecure property fits naturally into this model of urban equilibrium. In the non-commuting zone, rent is tied down by the value of land in agricultural use. The cost of city living then scales up with the cost of protecting one's title. As a consequence, larger properties become more expensive to maintain when title protection is weak. Higher effective housing costs then lead city dwellers to consume less land, which leads to higher density levels and lower welfare. A simple extension of the model would allow residents to invest in physical structures. If these were also subject to expropriation, structures would be smaller and cheaper structures when the right to possession is weak.

Within the commuting zone, rents always fall when title is less secure. Density also rises, and the city's overall footprint shrinks. Commute distances actually fall when title is insecure because the city as a whole gets smaller. Proposition 1 implies that the shape of the city depends on the property title regime. With weak property rights, people crowd more and consume less land.

Figure 4 shows a calibration of the model when $k=0$ and $k=.25$. We assume that the city population (M) is fixed at 100,000, $\mathrm{q}=.5, \alpha=20, r_{A}=100,000$ and $\mathrm{t}=4$, which implies that when title is secure $(k=0), 50,000$ people work in the city center, and the price of land at the city center is twice the price at the edge of the city. The two curves both show how density levels peak at the city center and then decline. At the urban edge, land price equals the price of agricultural land and density is flat because those residents are not commuting into the city center. The high curve shows the impact of 
insecure property rights, which raise density levels and make the city more compact. As the cost of defending property rises, the amount of property consumed falls and the city becomes more crowded.

Our cross-sectional data provides information on the share of the urban population living in a "slum." In our model, we define "slum conditions" as living at a density level greater than a threshold $d_{S}$. We recognize that there are millions of densely populated apartments that are not actually slums, which provide living space with significant physical capital investment. As our model has no investment in physical capital, we identify slum living - in the model - with high density.

Corollary 1: If $\frac{\alpha d_{S}-r_{A}}{r_{A}}>k>\frac{\alpha d_{S^{-}-5 q M t-r_{A}}}{r_{A}}$, then the urbanites who live less than the distance $\frac{\alpha}{t} \ln \left(\frac{q M t+2 r_{A}(1+k)}{2 \alpha d_{S}}\right)$ from the city center live in slums, and the share of the population living in slums increases from 0 to $\mathrm{q}$ as the protection of property rights gets weaker ( $\mathrm{k}$ rises). If $k>\frac{\alpha d_{S}-r_{A}}{r_{A}}$, then all of the urbanites live in slums and if $k<\frac{\alpha d_{S^{-} .5 q M t-r_{A}}}{r_{A}}$, then none of the urbanites live in slums.

Corollary 1 describes the connection between property rights and the prevalence of slums in our model. At the intermediate level of property rights, people living close to the city center live at higher than slum level densities. As property right become weaker, density levels increase and the physical footprint of slums rises as well. The share of the population living in slums falls as the protection of property rights improves, because the urbanites invest in more housing consumption.

This model predicts that slums are more prevalent near to the city center, but that might not be the case if we extended the model to include income heterogeneity. If we allowed for rich and poor urbanites, then those who could afford it will live closer to the city center to avoid commuting costs, and but not in slums. This pattern of income sorting can explain why developing world cities often have slums on the urban edge. A second explanation for slums far from the city center is that property rights were more poorly protected on the urban edge, making squatting easier. 
Our core results are unchanged if we assume the population of the city to be endogenous. To endogenize city population, we assume that migration to the city occurs until a resident's utility in the city equals utility in a reservation locale, denoted by $\underline{U}$, and we assume that the city is attractive enough to lure some people. We define $\mathrm{Z}$ as the constant that satisfies the equation $W-\alpha+$ $\alpha \ln (\alpha)-\alpha \ln (Z)=\underline{U}$, and then Proposition 1' follows:

Proposition 1' (Insecurity of Title, Open City): City population equals $\frac{2\left(Z-(1+k) r_{A}\right)}{q t}$ and is declining with k. If $|i|<\frac{\alpha}{t} \ln \left(\frac{Z}{(1+k) r_{A}}\right)$, then rent equals $p(i)=e^{-\frac{t}{\alpha}|i|}\left(\frac{Z}{(1+k)}\right)$ and density is given by $e^{-\frac{t}{\alpha}|i|}\left(\frac{Z}{\alpha}\right)$. If $\frac{\alpha}{t} \ln \left(\frac{Z}{(1+k) r_{A}}\right)+\frac{\alpha(1-q)\left(Z-(1+k) r_{A}\right)}{r_{A}(1+k) q t}>|i|>\frac{\alpha}{t} \ln \left(\frac{Z}{(1+k) r_{A}}\right)$, then rent equals $r_{A}$ and density is given by $(1+k) r_{A} / \alpha$. The average commute distance equals $\frac{\alpha q}{t}-\frac{r_{A}(1+k) \alpha q}{t\left(Z-(1+k) r_{A}\right)} \ln \left(\frac{Z}{(1+k) r_{A}}\right)$, which is decreasing with $\mathrm{k}$. Overall density is also rising with $\mathrm{k}$.

Holding the quality of legal regimes elsewhere constant, more insecure title in the city leads to a smaller population and a smaller physical footprint. Yet despite the city's shrinking population, overall density levels, or crowding, still rise. When population is endogenous, lot sizes become independent of title security within the inner commuting zone of the city, although the size of that zone shrinks as title security deteriorates. Within the outer, non-commuting zone, crowding increases as title security falls.

Crowding could actually cause traffic to get better when title becomes less secure. In contrast, the inability to transfer property - perhaps because the institutions of transfer are ineffective -- causes commuting distances to rise, which presumably makes traffic worse. To capture this cost, we assume that people must choose their location before they learn whether they will work in the city center or from home. The current model can be interpreted as one in which people buy housing at time zero, before they have learned their employment location, and then move after they learn where they will work at zero moving cost. Limits on the right to transfer make this cost positive. 
At the extreme, we now consider what happens when people cannot move after learning their employment status at time zero. This implies that some people who live far from city center end up with a long commute, and others live close to the city center without a formal job and work from home.

Everyone is assumed to have a probability " $q$ " of receiving a job at the city center, but then being stuck in place. Consumers are risk neutral over consumption, as suggested by our functional forms. With these assumptions Proposition 2 follows:

Proposition 2 (Inability to Transfer): If $|i|<\frac{\alpha}{t q} \ln \left(1+\frac{q M t}{2(1+k) r_{A}}\right)$, rent equals $p(i)=e^{-\frac{t q}{\alpha}|i|}\left(\frac{q M t}{2(1+k)}+r_{A}\right)$ and density equals $e^{-\frac{t q}{\alpha}|i|}\left(\frac{q M t}{2 \alpha}+\frac{(1+k) r_{A}}{\alpha}\right)$. The city ends where $|i|=\frac{\alpha}{t q} \ln \left(1+\frac{q M t}{2(1+k) r_{A}}\right)$, and density is zero. Over the entire city, density equals $\frac{2 \alpha}{t q M} \ln \left(\frac{2(1+k) r_{A}+q M t}{2(1+k) r_{A}}\right)$, which is declining with $\mathrm{k}$, and the average commute distance equals $\frac{\alpha}{t}-\frac{2 r_{A}(1+k) \alpha}{t^{2} M q} \ln \left(1+\frac{q M t}{2 r_{A}(1+k)}\right)$ which is higher than $\frac{\alpha q}{t}-$ $\frac{2 r_{A}(1+k) \alpha}{t^{2} M} \ln \left(1+\frac{q M t}{2 r_{A}(1+k)}\right)$

Proposition 2 tells us that rents and density at the city center are the same regardless of the possibility of land transfer, but both decline more slowly with distance to the city center when there is no ability to transfer property. The city as a whole becomes larger and density lower, because the willingness to pay declines more slowly. The rent and density at the city center are not impacted because the flatter slope of rents and densities is offset by the longer distance to the city's edge.

Figure 5 shows the impact of inability to transfer on density levels. The two graphs use the same parameter values as Figure 4, and k=0 for both. The lower curve is identical to the curve with strong title protection in Figure 4; the higher curve shows the equilibrium density levels when there is no ability to transfer title. The city's boundaries shrink. With a more compact city, density is also higher everywhere 
that the city is inhabited. This densification works to reduce, but not to eliminate, the longer average commutes created by the spatial mismatch.

Commute distances become longer because of two related effects. First, there are people who live close to the city center but are still working at home because they cannot move further out. They are pushing out people who would love to live closer but cannot readjust their location after getting jobs in the city center. Second, the city has gotten larger because willingness to pay declines more slowly with distance from the city center.

These two propositions shape our empirical work on property title, property transfer, and urban form. The first proposition generates the prediction that insecurity of title should lead to higher density levels, or equivalently smaller lot sizes.

We also identify this prediction with the proportion of people living in slums, which are defined by the U.N. as residences that lack "sufficient living space" or "durable housing of a permanent nature." In our model, lot size determines living space, and the weak possession right therefore implies that living space may be insufficient. If we enriched the model to allow structures that are also subject to expropriation, then a limited right to possession would also imply less durable housing. ${ }^{6}$ Weak title protection may also deter the building of apartments, because developers fear to lose their property.

Insecure title does not lead to longer commutes or more congestion. Proposition 2 generates the prediction that inability to transfer property leads to a greater mismatch between people and jobs. Because we do not have consistent data on commute time and distance, we measure excess driving with the level of congestion, which should be greater if spatial mismatch is more severe.

\footnotetext{
${ }^{6}$ If it costs $f(H)$ to provide housing that deliver the utility equivalent of $H$ units of the consumption good, where $\mathrm{f}(\mathrm{H})$ is increasing and convex and if it cost $\mathrm{kH}$ to defend that housing, then the first order condition for housing would be 1-k=f'(H). The convex costs imply that the optimal level of $\mathrm{H}$ is falling with the need for self-protection.
} 


\section{Title, Transfer and Urban Form}

We next turn to the correlations between our property rights measures and urban outcomes. As discussed above, security of title and ease of transfer - or title and transfer for short - should have different impacts on two vital aspects of urban life. Security of title should impact the incentive to invest in housing quality. Ease of transfer should impact the allocation of space to its most efficient users. We begin with our measures of housing quality and then turn to the allocation of space within cities.

\section{Residential Quality, Title and Transfer}

According to Proposition 1, insecurity of title leads to higher urban density and more slums. We start with our preferred measure of housing quality: the share of the population living in a slum as measured by the United Nations. The United Nations "defines a slum household as a group of individuals living under the same roof in an urban area who lack one or more of the following: 1 . Durable housing of a permanent nature that protects against extreme climate conditions. 2. Sufficient living space which means not more than three people sharing the same room. 3. Easy access to safe water in sufficient amounts at an affordable price. 4. Access to adequate sanitation in the form of a private or public toilet shared by a reasonable number of people. 5 . Security of tenure that prevents forced evictions." ${ }^{\prime 7}$ The first four conditions listed in this definition relate to the physical nature of the structure. The fifth condition echoes the title security measures that we use as dependent variables, and for this reason, we also use other outcomes that are not potentially biased by this overlap.

The first column of Table 4 relates this variable to our measures of title security. The column presents five regressions (all of which control for the logarithm of per capita GDP), and shows the coefficients on both Title and GDP. The coefficient on GDP is always strongly negative, ranging from

\footnotetext{
${ }^{7}$ https://mirror.unhabitat.org/documents/media centre/sowcr2006/SOWCR\%205.pdf
} 
about -12 to -15 . The value of -13 implies that as its level increases by one log point (or approximately 170 percent), the share of the population living in a slum falls by 13 percentage points.

In the top regression, the coefficient on the Title index is -1.45 . As the standard deviation of this variable is 7.5, a one standard deviation improvement in Title is associated with a 10.88 percentage point reduction in the share of the population living in slums. If we use the -12.26 coefficient on GDP in this regression, these coefficients imply that a one standard deviation improvement in Title is associated with the same improvement in housing conditions as a 143 percent increase in income. The t-statistic on this coefficient is 3.83 , suggesting that its magnitude is both statistically and economically meaningful.

We next consider individual subindices. The second regression shows our results for reliability of property title infrastructure. This variable captures the accessibility of property titles, including electronic access and centralized location. The coefficient is -2.64 and the standard error is .88 , so again it is statistically different from zero. The third regression turns to the transparency of information about property title. The statistical relationship between this transparency measure and slums is even stronger. The coefficient is -5.272 , with a t-statistic of 3.78 . A one standard deviation increase in this variable is associated with a 7.48 percentage point fall in the share of people living in slums.

The fourth regression focuses on the geographic coverage of land titling information. This measure refers to the share of land that is formally registered and mapped. This variable is less strongly correlated with the slum share outcome. The coefficient is -2.12 and the t-statistic is just slightly over two. The final regression looks at the dispute resolution subindex. While effective dispute resolution looms large in the desiderata for any property title system, the components in this index may not determine the quality of dispute resolution on the ground. For example, the availability of the number of title disputes may not actually matter for a slum dweller who is trying to protect his home against expropriation. The coefficient is negative, but it is statistically indistinct from zero and small. 
Overall, the title variables correlate strongly with slum share even when controlling for income. These correlations do not prove a causal link, but are consistent with the predictions of Proposition 1.

Columns (2)-(4) look at density and average property size. Column (2) shows that overall population density is negatively correlated with the overall index and all four subindices, as predicted by Proposition 1 . In three cases, the correlation is statistically significant at conventional levels. A one standard deviation increase in the overall title index is associated with .23 log point (or about 25 percent) decrease in urban density, which is quite meaningful. A one standard deviation increase in the reliability of title infrastructure is associated with a fall of density of about 30 percent.

In columns (3) and (4), we turn to average plot size for the Urban Atlas. The Atlas presents the plot size variables for formal and informal plots in the city. The titling system would presumably be irrelevant for informal settlements if these areas had no formal title whatsoever. However, informal settlements often have formal title but the occupants are squatting, or they are "unplanned settlements and areas where housing is not in compliance with current planning and building regulations." ${ }^{8}$ To the extent that the owners of informal housing are also protected by the titling system, the model's implication that weak title leads to smaller lot size stands. The poorer owners of these lots are particularly vulnerable to expropriation, so weaker title reduces their willingness to invest the most. ${ }^{9}$

Title is positively associated with both formal and informal lot size, and the coefficient is statistically significant in the informal lot size regression at the $10 \%$ level. The component of the index with the strongest relationship with lot size is the quality dispute resolution. This measure is statistically

\footnotetext{
${ }^{8}$ https://stats.oecd.org/glossary/detail.asp?ID=1351.

9 The largest informal lot sizes in our data are the cities of former socialist countries, such as Warsaw and Kiev. The informal lots there are not the lawless slums of poor countries, but former public housing not yet fully formalized.
} 
significant in both regressions. Overall, these results provide some evidence, in line with Proposition 1, connecting housing quality (our measure of investment) with the strength of the title.

Table 5 shows the same basic patterns with our measures of transfer, including financial costs, time costs, the number of procedures involved in transferring property, and the Transfer index. Our model predicts that these variables should not be helpful in predicting housing quality, and that is indeed what we find. Only transfer cost is associated with slum share, as shown in the first column. All three variables, as well as the Transfer index, are correlated with the density of the built-up area, but as we show in column (6), these correlations turn weaker or disappear when we control for the Title index. The regression in column (5) shows that Title is significantly correlated with the slum share in all specifications, but the transfer variables generally do not predict slum share once we control for Title.

Our model predicts that the right to possess and the right to transfer should have different implications for plot size, or the physical quality of housing. Just as the model predicts, weak title protection is associated with higher density and greater prevalence of slums. Stronger transfer rights are not associated with any of these outcomes, once we control for Title.

\section{Spatial Mismatch, Title and Transfer}

We next turn to our spatial mismatch variable, which according to Proposition 2 is more likely to be correlated with Transfer costs than with the security of Title. The inability to buy and sell homes means that as people's economic conditions change, they find it difficult to relocate. We should expect to see longer commutes when the transfer of property becomes more difficult. Ideally, we would identify longer commutes with the physical distance between work and home. Unfortunately, we do not have that data for a sufficiently large sample of our cities, and instead use the TomTom data on congestion. The extra driving that comes from an inability to adapt residential location leads to more congestion as long as road infrastructure construction does not improve to match new travel demand. 
Table 6 has four columns. The outcome is the TomTom congestion measure defined as the extra time added by traffic on a basic car trip. In the first column, we show the there is a significant correlation between the number of procedures needed to transfer property and the congestion index. In columns (2) and (3), we show that neither the logarithm of time to transfer property nor the financial cost of transferring property is statistically significant at conventional levels, but both coefficients are positive and more than one standard error greater than zero. Finally, in the last regression, we show the results using Transfer, which sums the z-scores of our three measures of barriers. Again, inefficient transfer is associated with increased travel time.

In all specifications, the coefficient of the title variable is zero. In our model, better Title could even reduce travel times, because density increases. We do not find that negative impact, but we do find support for the Proposition 2 prediction that difficulty of transfer, but not the security of title, increases the spatial mismatch between work and home. Travel congestion falls with log GDP, which may be because richer countries are building high rises close to city centers, or spending more on the infrastructure which can reduce travel times.

Our final test, which falls outside the predictions of the model, considers the penetration of housing loans in a country. Theoretically, mortgage lending relies both on reliable title, since the lender requires valid collateral, and reliable transfer procedures, since the lender must be able to repossess and sell collateral should the borrower default. Figures 6 and 7 present the relationships between Title and Transfer, respectively, and housing loan penetration. The results are consistent with the obvious theoretical prediction, namely that both possession and transfer rights are associated with greater housing loan penetration. At the same time, these graphs do not control for per capita income, and housing loan penetration is extremely low in poor countries across the quality of property rights institutions. In the regressions, we take these concerns into account. 
Table 7 presents the regressions controlling for log GDP per capita. The first three columns show that, in the full sample, controlling for per capita income, housing loan penetration is significantly affected by both Title and Transfer, although only the latter variable survives when both are included in the regression. Column (4) shows that this result also holds if we focus only on the subsample of richer countries, where we see most variation in housing loan penetration. Column (5) shows interestingly that the same result on the central role of transfer institutions holds also for rural housing loan penetration, which has not been the focus of our analysis.

Tables 5, 6, and 7 together illustrate how different elements in the bundle of property rights have different impacts on urban form. As the model predicts, stronger protection of possession is correlated with more land per person and better quality of physical housing. Easier land transfer is not correlated with these outcomes, but is negatively correlated with the congestion times. These findings suggest that the efficiency of land allocation depends on the ability to transfer property, but the quality of living space depends on the ability to possess it. In addition, Table 7 shows that the penetration of housing loans depends on both the security of title and on the number of transfer procedures, but especially on the latter. This is a significant result since, as we have noted, most economic research has focused on the benefits of title rather than transfer institutions for economic outcomes.

\section{The evolution of Title and Transfer over time.}

We have focused on the effect of Title and Transfer rules on urban form, and showed that poor property rights protection is often associated with inefficient urban outcomes, such as slums and traffic congestion, as well as with stunted mortgage markets. These findings raise the question of whether these rules are getting better or worse over time. Many legal institutions in the world, including the inefficient ones, persist for decades and even centuries and can be driven by their intimate connection 
to a country's legal tradition (La Porta et al 2008, Balas et al 2009). But there are other institutions, such as the regulation of entry, that have been improving dramatically over time (Djankov 2009).

The rules of Title and Transfer are not related to legal traditions, but do they change? Increased urban growth is likely to increase the costs of weak possession rights and of inefficient property transfers. An optimistic hypothesis, inspired by Demsetz (1967), is that these increased costs will lead polities to invest in the fixed costs needed to reform their institutions. A related view holds that technological change makes it easier to register and transfer title electronically and thus effectively lowers the cost of securing property rights. A pessimistic view would maintain, in contrast, that economic and political changes empower interest groups to impose new limitations on transfer or create more risk of expropriation.

Figure 8 supports for the more optimistic view. We have only limited time series data on Title institutions between 2015 and 2019, but the evidence in Panel A shows that our composite measure of Title has been improving in countries in all income groups. In contrast, we have 16 years of data on Transfer rules, and find for procedures, time, and cost an improvement for countries of all income levels. Panel B shows a decline in the number of transfer procedures, particularly in countries in the bottom two income quintiles. Panels $C$ and $D$ show large reductions for Transfer time and Transfer cost, again present at all income levels, but particularly dramatic for the poor countries.

We examined a number of country-specific case studies about reform and found that much of this improvement is apolitical and technocratic. In many cases, new technologies, especially electronic record keeping, drive the reduction in time and cost. In other cases, procedures fell because of a bureaucratic push towards simplification. These findings support Demsetz's (1967) observation that - at least some - institutions evolve toward lower transaction costs and a more efficient form. 


\section{Conclusion}

The Blackstonian bundle of property rights is not merely a theoretical construct. The strength of the different rights that are associated with land ownership can be measured. They can be analyzed as distinct, but related forces that shape economic development and urban form.

We have focused on rights related to possession of title and those related to ease of transfer in 190 countries. These institutions differ significantly across cities and countries. Some places make it extremely difficult to transfer property, while others offer limited protection of possession. As policyreformers have limited capacity to reform institutions, scholars must develop a richer understanding of the value of the different types of property rights.

The work in this paper suggests that both theoretically and empirically, the right to possession and the right to transfer have different impacts on urban form. Weak possession rights reduce the incentives to build better housing or own more land. The empirical link between limited title and urban slums is in line with our theory. Limited ability to transfer property makes it difficult to match workplace with home location. The empirical link between the number of procedures needed to transfer property and traffic congestion is also consistent with our model. Finally, we also showed that the development of housing loan finance relies on both title and transfer institutions, but especially the latter.

While many countries provide only weak protection of title and pose many barriers to transfer, the good news is that these institutions are improving in most countries, and particularly in the developing world. In line with Demsetz (1967), protection of property rights is costly, but still, over time, the world appears to be moving toward more efficient outcomes. As Demsetz (1967) predicted, as technology lowers the cost of improving property rights, those rights eventually improve. 


\section{References}

Acemoglu, Daron, Simon Johnson and James A. Robinson. 2001. The Colonial Origins of Comparative Development: An Empirical Investigation. American Economic Review 91(5): 1369-1401.

Alchian, Armen. 2008. Property Rights. The Concise Encyclopedia of Economics.

Balas, Aron, Rafael La Porta, Florencio Lopez-de-Silanes and Andrei Shleifer. 2009. The Divergence of Legal Procedures. American Economic Journal: Economic Policy 1(2): 138-162.

Barro, Robert J. 1990. Economic Growth in a Cross Section of Countries. Quarterly Journal of Economics 106(2): 407-443.

Barzel, Yoram. 1982. Measurement Cost and the Organization of Markets. Journal of Law and Economics 25(1): 27-48.

Behrer, A. Patrick, Edward Glaeser, Giacomo Ponzetto and Andrei Shleifer. 2021. Security property rights. Journal of Political Economy 129(4): 1157-1192.

Besley, Timothy J. 1995. Property Rights and Investment Incentives: Theory and Evidence from Ghana. Journal of Political Economy 103(5): 903-937.

Brueckner, Jan. 1987. The Structure of Urban Equilibria: A Unified Treatment of the Muth-Mills Model. Handbook of Regional and Urban Economics 2: 821-845.

Chong, Alberto, Rafael La Porta, Florencio Lopez-de-Silanes and Andrei Shleifer. 2014. Letter Grading Government Efficiency. Journal of the European Economic Association 12(2): 277-299.

Collier, Paul and Anthony Venables. 2014. Closing Coal: Economic and Moral Incentives. Oxford Review of Economic Policy 30(3): 492-512.

De Long, J. Bradford, and Andrei Shleifer. 1993. Princes and Merchants: European City Growth Before the Industrial Revolution. Journal of Law and Economics 36(2): 671-702.

Demsetz, Harold. 1967. Towards a Theory of Property Rights. American Economic Review 57: 347-59.

De Soto, Hernando. 1989. The Other Path: The Invisible Revolution in the Third World. New York, NY: Harper and Row.

De Soto, Hernando. 2000. The Mystery of Capital: Why Capitalism Triumphs in the West and Fails Everywhere Else. New York, NY: Basic Books.

Djankov, Simeon. 2009. The Regulation of Entry: A Survey. The World Bank Research Observer 24(2): 183-2013.

Djankov, Simeon, Rafael La Porta, Florencio Lopez-de-Silanes and Andrei Shleifer. 2003. Courts. The Quarterly Journal of Economics 118(2): 453-517.

Ellickson, Robert. 1993. Property in Land. Yale Law Journal 102: 1315-1400.

Field, Erica M. 2005. Property Rights and Investment in Urban Slums. Journal of the European Economic Association 3(2-3): 279-290. 
Field, Erica M. 2007. Entitled to Work: Urban Tenure Security and the Labor Supply in Peru. Quarterly Journal of Economics 122(4): 1561-1602.

Glaeser, Edward, Rafael La Porta, Florencio Lopez-de-Silanes and Andrei Shleifer. 2004. Do Institutions Cause Growth. Journal of Economic Growth 9: 271-303.

Glaeser, Edward and Erzo Luttmer. 2003. The misallocation of housing under rent control. American Economic Review 93(4): 1027-1046.

La Porta, Rafael, Florencio López-de-Silanes, Cristian Pop-Eleches, and Andrei Shleifer. 2004. Judicial Checks and Balances. Journal of Political Economy 112(2): 445-470.

La Porta, Rafael, Florencio Lopez-de-Silanes and Andrei Shleifer. 2008. The Economic Consequences of Legal Origins. Journal of Economic Literature 46(2): 285-332.

La Porta, Rafael, Florencio Lopez-de-Silanes, Andrei Shleifer and Robert Vishny. 1999. The quality of government. The Journal of Law, Economics, and Organization 15(1): 222-279.

Montesquieu, Charles de Secondat, baron de. 1748. De l'esprit des lois. Geneva: Barrillot et fils.

North, Douglass C. 1981. Structure and Change in Economic History. New York: Norton.

Olson, Mancur. 1965. The logic of collective action: public goods and the theory of groups. Cambridge, Mass: Harvard University Press.

Olson, Mancur. 1993. Dictatorship, Democracy, and Development. American Political Science Review 87 (3): 567-76.

Shleifer, Andrei and Robert Vishny. 1998. The Grabbing Hand. Cambridge, Mass: Harvard University Press.

Smith, Adam. 1776. An Inquiry into the Nature and Causes of the Wealth of Nations. London: W. Strahan and T. Cadell. 


\section{Table 1: Variable Descriptions}

\begin{tabular}{|c|c|c|}
\hline Variable & Label & Level \\
\hline Title & Security of Title (0-30) in 2015 & City \\
\hline Reliability of Infrastructure & Reliability of Infrastructure Index (0-8) in 2015 & City \\
\hline Transparency of Information & Transparency of Information Index (0-6) in 2015 & City \\
\hline Geographic Coverage & Geographic Coverage Index (0-8) in 2015 & City \\
\hline Land Dispute Resolution & Land Dispute Resolution Index (0-8) in 2015 & City \\
\hline Transfer & Property transfer efficiency index in 2019 & City \\
\hline Transfer procedures & Procedures to transfer property (number) & City \\
\hline Transfer time & Time to transfer property (days) & City \\
\hline Transfer cost & Cost to transfer property (\% of property value) & City \\
\hline UN Slum Share & $\begin{array}{l}\text { UN HABITAT, Population living in slums (\% of urban pop) in } \\
2014\end{array}$ & Country \\
\hline Log(Built Up Area Density) & UA2, Built-up Area Density (persons/ha) (circa 2013) & City \\
\hline Log(Formal Lot Size) & UA1, Average Plot Size in Formal Land Subdivisions in 2015 & City \\
\hline Log(Informal Lot Size) & UA1, Average Plot Size in Informal Land Subdivisions in 2015 & City \\
\hline $\log (G D P)$ & WDI, log of GDP & Country \\
\hline Government effectiveness & WB, WGI Government effectiveness (-2.5 - 2.5) & Country \\
\hline Human Capital & WB, Human Capital Index (2020) (0-1) & Country \\
\hline TomTom congestion level & Congestion (\% more travel time than in baseline traffic) & City \\
\hline $\begin{array}{l}\text { Expropriation with adequate } \\
\text { compensation }\end{array}$ & $\begin{array}{l}\text { WJP, The government does not expropriate without lawful } \\
\text { process and adequate compensation }(0-1)\end{array}$ & Country \\
\hline Housing Loan Penetration & $\begin{array}{l}\text { WB, Percentage of adult population with an outstanding loan } \\
\text { to purchase a home }\end{array}$ & Country \\
\hline
\end{tabular}


Table 2: The Improvement of Title and Transfer Rules with Economic Development

\begin{tabular}{|c|c|c|c|c|c|c|c|c|c|}
\hline & Title & $\begin{array}{l}\text { Reliability of } \\
\text { Infrastructure }\end{array}$ & $\begin{array}{l}\text { Transparency } \\
\text { of } \\
\text { Information }\end{array}$ & $\begin{array}{l}\text { Geographic } \\
\text { Coverage }\end{array}$ & $\begin{array}{l}\text { Land } \\
\text { Dispute } \\
\text { Resolution } \\
\end{array}$ & $\begin{array}{l}\text { Transfer } \\
\text { procedures }\end{array}$ & $\begin{array}{l}\text { Transfer } \\
\text { cost }\end{array}$ & $\begin{array}{l}\text { Transfer } \\
\text { time }\end{array}$ & Transfer \\
\hline Log(GDP per capita) & $\begin{array}{l}3.393 * * * \\
(0.286)\end{array}$ & $\begin{array}{l}1.255^{* * *} \\
(0.114)\end{array}$ & $\begin{array}{l}0.389 * * * \\
(0.0658)\end{array}$ & $\begin{array}{l}1.313^{* * *} \\
(0.129)\end{array}$ & $\begin{array}{l}0.400 * * * \\
(0.0688)\end{array}$ & $\begin{array}{l}-0.234^{* *} \\
(0.110)\end{array}$ & $\begin{array}{l}-0.790 * * * \\
(0.216)\end{array}$ & $\begin{array}{l}-10.64 * * * \\
(2.576)\end{array}$ & $\begin{array}{l}-0.538^{* * *} \\
(0.100)\end{array}$ \\
\hline Human capital index & $\begin{array}{l}41.72 * * * \\
(2.532)\end{array}$ & $\begin{array}{l}15.33 * * * \\
(1.071)\end{array}$ & $\begin{array}{l}5.513 * * * \\
(0.650)\end{array}$ & $\begin{array}{l}14.95^{* * * *} \\
(1.329)\end{array}$ & $\begin{array}{l}5.482 * * * \\
(0.670)\end{array}$ & $\begin{array}{l}-3.740 * * * \\
(1.183) \\
\end{array}$ & $\begin{array}{l}-12.51^{* * *} \\
(2.176) \\
\end{array}$ & $\begin{array}{l}-131.3^{* * *} \\
(27.46)\end{array}$ & $\begin{array}{l}-7.698 * * * \\
(1.013)\end{array}$ \\
\hline $\begin{array}{l}\text { Government } \\
\text { effectiveness }\end{array}$ & $\begin{array}{l}5.511 * * * \\
(0.394)\end{array}$ & $\begin{array}{l}1.953 * * * \\
(0.163)\end{array}$ & $\begin{array}{l}0.767^{* * *} \\
(0.0918)\end{array}$ & $\begin{array}{l}2.094 * * * \\
(0.181)\end{array}$ & $\begin{array}{l}0.626 * * * \\
(0.103)\end{array}$ & $\begin{array}{l}-0.613^{* * *} \\
(0.161)\end{array}$ & $\begin{array}{l}-1.349 * * * \\
(0.342)\end{array}$ & $\begin{array}{l}-17.15^{* * *} \\
(3.798)\end{array}$ & $\begin{array}{l}-1.015^{* * *} \\
(0.145)\end{array}$ \\
\hline
\end{tabular}

\section{Table 3 - Partial correlations between Title and Transfer indices}

\begin{tabular}{|c|c|c|c|c|c|c|c|c|}
\hline & Title & $\begin{array}{l}\text { Transfer } \\
\text { Procedures }\end{array}$ & $\begin{array}{l}\text { Transfer } \\
\text { Time }\end{array}$ & $\begin{array}{l}\text { Transfer } \\
\text { Cost }\end{array}$ & $\begin{array}{l}\text { Reliability of } \\
\text { Infrastructure }\end{array}$ & $\begin{array}{l}\text { Transparency } \\
\text { of } \\
\text { Information }\end{array}$ & $\begin{array}{l}\text { Geographic } \\
\text { Coverage }\end{array}$ & $\begin{array}{l}\text { Land } \\
\text { Dispute } \\
\text { Resolution }\end{array}$ \\
\hline Transfer Procedure & $-0.296 * * *$ & & & & & & & \\
\hline Transfer Time & $-0.319 * * *$ & $0.206 * * *$ & & & & & & \\
\hline $\begin{array}{l}\text { Transfer Cost } \\
\text { Reliability of }\end{array}$ & $-0.377^{* * *}$ & $0.130 *$ & $0.157^{* *}$ & & & & & \\
\hline $\begin{array}{l}\text { Infrastructure } \\
\text { Transparency of }\end{array}$ & $0.849 * * *$ & $-0.280 * * *$ & $-0.317 * * *$ & $-0.412 * * *$ & & & & \\
\hline $\begin{array}{l}\text { Information } \\
\text { Geographic }\end{array}$ & $0.581^{* * *}$ & $-0.144 *$ & $-0.271 * * *$ & $-0.243 * * *$ & $0.473^{* * *}$ & & & \\
\hline $\begin{array}{l}\text { Coverage } \\
\text { Land Dispute }\end{array}$ & $0.770 * * *$ & $-0.192 * * *$ & -0.114 & $-0.189 * *$ & $0.453 * * *$ & $0.167^{* *}$ & & \\
\hline Resolution & $0.706 * * *$ & $-0.286 * * *$ & $-0.308 * * *$ & $-0.238 * *$ & $0.520 * * *$ & $0.328 * * *$ & $0.405 * * *$ & \\
\hline Transfer & $-0.493 * * *$ & $0.743 * * *$ & $0.502 * * *$ & $0.638 * * *$ & $-0.501 * * *$ & $-0.349 * * *$ & $-0.244 * * *$ & $-0.396 * * *$ \\
\hline
\end{tabular}

Note - Partial correlation controlled for per capita income. ${ }^{*} p<0.1 * * p<0.05 * * * p<0.01$ show the level of statistical significance of the amount R2 decreases by removing a variable from the regression. 
Table 4 - Urban Form Outcomes and Title.

\begin{tabular}{lllll} 
& UN Slum Share & $\begin{array}{l}\text { Log(Built Up } \\
\text { Area Density) }\end{array}$ & $\begin{array}{l}\text { Log (Formal } \\
\text { Lot Size) }\end{array}$ & $\begin{array}{l}\text { Log (Informal } \\
\text { Lot Size) }\end{array}$ \\
\hline Title & $-1.449^{* * *}$ & $-0.0304^{* * *}$ & 0.0207 & $0.0402^{*}$ \\
& $(0.378)$ & $(0.0114)$ & $(0.0170)$ & $(0.0222)$ \\
Log(GDP per capita) & $-12.26^{* * *}$ & $-0.144^{* *}$ & 0.116 & 0.0537 \\
& $(1.937)$ & $(0.0612)$ & $(0.0931)$ & $(0.127)$ \\
\hline Reliability of Infrastructure & $-2.640^{* * *}$ & $-0.104^{* * *}$ & 0.0229 & $0.128^{* *}$ \\
& $(0.884)$ & $(0.0281)$ & $(0.0441)$ & $(0.0514)$ \\
Log(GDP per capita) & $-12.92^{* * *}$ & $-0.117^{* *}$ & $0.171^{*}$ & 0.0157 \\
& $(2.012)$ & $(0.0564)$ & $(0.0906)$ & $(0.119)$ \\
\hline Transparency of Information & $-5.272^{* * *}$ & -0.0572 & 0.0190 & -0.0384 \\
& $(1.395)$ & $(0.0550)$ & $(0.0682)$ & $(0.104)$ \\
Log(GDP per capita) & $-13.79^{* * *}$ & $-0.237^{* * *}$ & $0.201 * * *$ & $0.236^{* *}$ \\
& $(1.777)$ & $(0.0502)$ & $(0.0609)$ & $(0.111)$ \\
\hline Geographic Coverage & $-2.119^{* *}$ & -0.0219 & 0.0341 & 0.0196 \\
& $(1.042)$ & $(0.0268)$ & $(0.0377)$ & $(0.0528)$ \\
Log(GDP per capita) & $-14.80^{* * *}$ & $-0.227^{* * *}$ & 0.143 & 0.189 \\
& $(1.875)$ & $(0.0612)$ & $(0.0906)$ & $(0.118)$ \\
\hline Land Dispute Resolution & -2.006 & $-0.101^{* *}$ & $0.112^{*}$ & $0.171^{* *}$ \\
Log(GDP per capita) & $(1.626)$ & $(0.0456)$ & $(0.0620)$ & $(0.0754)$ \\
& $-15.10^{* * *}$ & $-0.214^{* * *}$ & $0.153^{* *}$ & 0.125 \\
N & $(1.946)$ & $(0.0482)$ & $(0.0613)$ & $(0.0973)$ \\
& 80 & 65 & 52 & 40
\end{tabular}

Note - All models are multivariate regression controlling for per capita income. Standard errors in parentheses. ${ }^{*} p<0.1{ }^{* *} p<0.05 * * * p<0.01$ 
Table 5 - Urban Form Outcomes and Transfer.

\begin{tabular}{|c|c|c|c|c|c|c|}
\hline & $\begin{array}{l}\text { UN Slum } \\
\text { Share }\end{array}$ & $\begin{array}{l}\text { Log(Built Up } \\
\text { Area Density) }\end{array}$ & $\begin{array}{l}\text { Log(Formal Lot } \\
\text { Size) }\end{array}$ & $\begin{array}{l}\text { Log } \\
\text { (Informal Lot } \\
\text { Size) }\end{array}$ & UN Slum Share & $\begin{array}{l}\text { Log(Built Up } \\
\text { Area Density) }\end{array}$ \\
\hline Transfer Procedure & $\begin{array}{l}-0.199 \\
(1.005)\end{array}$ & $\begin{array}{l}0.0599 * * \\
(0.0281)\end{array}$ & $\begin{array}{l}-0.00328 \\
(0.0368)\end{array}$ & $\begin{array}{l}0.00536 \\
(0.0491)\end{array}$ & $\begin{array}{l}-0.640 \\
(0.931)\end{array}$ & $\begin{array}{l}0.0415 \\
(0.0286)\end{array}$ \\
\hline Title & & & & & $\begin{array}{l}-1.481^{* * *} \\
(0.382)\end{array}$ & $\begin{array}{l}-0.0252^{* *} \\
(0.0119)\end{array}$ \\
\hline Log(GDP per capita) & $\begin{array}{l}-15.93^{* * *} \\
(1.852)\end{array}$ & $\begin{array}{l}-0.236 * * * \\
(0.0449)\end{array}$ & $\begin{array}{l}0.206 * * * \\
(0.0596)\end{array}$ & $\begin{array}{l}0.217^{* *} \\
(0.0972)\end{array}$ & $\begin{array}{l}-11.99 * * * \\
(0.931)\end{array}$ & $\begin{array}{l}-0.147^{* *} \\
(0.0607)\end{array}$ \\
\hline Log(Transfer time) & $\begin{array}{l}-0.4839 \\
(2.467)\end{array}$ & $\begin{array}{l}0.1323 * * \\
(0.0645)\end{array}$ & $\begin{array}{l}0.0267 \\
(0.0846)\end{array}$ & $\begin{array}{l}-0.0964 \\
(0.1330)\end{array}$ & $\begin{array}{l}-5.638^{* *} \\
(2.477)\end{array}$ & $\begin{array}{l}0.0830 \\
(0.0673)\end{array}$ \\
\hline Title & & & & & $\begin{array}{l}-1.881 * * * \\
(0.414)\end{array}$ & $\begin{array}{l}-0.0250^{* *} \\
(0.0122)\end{array}$ \\
\hline Log(GDP per capita) & $\begin{array}{l}-16.110^{* * *} \\
(1.939)\end{array}$ & $\begin{array}{l}-0.2104^{* * *} \\
(0.0500)\end{array}$ & $\begin{array}{l}0.219 * * * \\
(0.0651)\end{array}$ & $\begin{array}{l}0.1881^{*} \\
(0.101) \\
\end{array}$ & $\begin{array}{l}-12.623^{* * *} \\
(1.894)\end{array}$ & $\begin{array}{l}-0.133^{* *} \\
(0.0616) \\
\end{array}$ \\
\hline Transfer Cost & $\begin{array}{l}1.036^{* *} \\
(0.413)\end{array}$ & $\begin{array}{l}0.0330^{*} \\
(0.0190)\end{array}$ & $\begin{array}{l}-0.00106 \\
(0.0222)\end{array}$ & $\begin{array}{l}-0.0495 \\
(0.0321)\end{array}$ & $\begin{array}{l}0.4861 \\
(0.433)\end{array}$ & $\begin{array}{l}0.0234 \\
(0.0188)\end{array}$ \\
\hline Title & & & & & $\begin{array}{l}-1.252^{* * *} \\
(0.416)\end{array}$ & $\begin{array}{l}-0.027 * * \\
(0.0117)\end{array}$ \\
\hline Log(GDP per capita) & $\begin{array}{l}-15.22^{* * *} \\
(1.785)\end{array}$ & $\begin{array}{l}-0.246^{* * *} \\
(0.0448)\end{array}$ & $\begin{array}{l}0.208 * * * \\
(0.0554)\end{array}$ & $\begin{array}{l}0.171^{*} \\
(0.0962)\end{array}$ & $\begin{array}{l}-12.40 * * * \\
(1.938)\end{array}$ & $\begin{array}{l}-0.145 * * \\
(0.061)\end{array}$ \\
\hline Transfer & $\begin{array}{l}1.3516 \\
(1.157)\end{array}$ & $\begin{array}{l}0.0827 * * \\
(0.0311)\end{array}$ & $\begin{array}{l}0.00286 \\
(0.0398)\end{array}$ & $\begin{array}{l}-0.045 \\
(0.0582)\end{array}$ & $\begin{array}{l}-0.896 \\
(1.235)\end{array}$ & $\begin{array}{l}0.0598^{*} \\
(0.0331)\end{array}$ \\
\hline Title & & & & & $\begin{array}{l}-1.605 * * * \\
(0.4361)\end{array}$ & $\begin{array}{l}-0.0219^{*} \\
(0.0122)\end{array}$ \\
\hline Log(GDP per capita) & $\begin{array}{l}-15.64 * * * \\
(1.836)\end{array}$ & $\begin{array}{l}-0.2093 * * * \\
(0.0468)\end{array}$ & $\begin{array}{l}0.2102 * * * \\
(0.0621)\end{array}$ & $\begin{array}{l}0.1866^{*} \\
(0.101)\end{array}$ & $\begin{array}{l}-12.081^{* * *} \\
(1.958)\end{array}$ & $\begin{array}{l}-0.139 * * \\
(0.0602)\end{array}$ \\
\hline $\mathrm{N}$ & 80 & 65 & 52 & 40 & 80 & 65 \\
\hline
\end{tabular}

Note - All models are multivariate regression controlling for per capita income. Standard errors in parentheses. ${ }^{*} p<0.1{ }^{* *} p<0.05 * * * p<0.01$ 
Table 6: Spatial Mismatch and Transfer.

\begin{tabular}{lcccc}
\hline & $\begin{array}{c}(1) \\
\text { Traffic } \\
\text { Congestion }\end{array}$ & $\begin{array}{c}(2) \\
\text { Traffic } \\
\text { Congestion }\end{array}$ & $\begin{array}{c}(3) \\
\text { Traffic } \\
\text { Congestion }\end{array}$ & $\begin{array}{c}(4) \\
\text { Traffic } \\
\text { Congestion }\end{array}$ \\
\hline Transfer procedures & $\begin{array}{c}\text { (0133** } \\
\text { (0.00587) }\end{array}$ & & & \\
Log(Transfer time) & & 0.0151 & & \\
& & $(0.0127)$ & & \\
Transfer Cost & & & 0.00559 & \\
& & & $(0.00418)$ & \\
Transfer & & & & $0.0149 * *$ \\
& & & & $(0.00669)$ \\
Title & 0.000445 & -0.00125 & -0.00119 & 0.000276 \\
Log(GDP per capita) & $(0.00268)$ & $(0.00262)$ & $(0.00261)$ & $(0.00266)$ \\
& $-0.0668^{* * *}$ & $-0.0697^{* * *}$ & $-0.0748^{* * *}$ & $-0.0685^{* * *}$ \\
Constant & $(0.0153)$ & $(0.0158)$ & $(0.0156)$ & $(0.0152)$ \\
& $0.953^{* * *}$ & $1.048^{* * *}$ & $1.118^{* * *}$ & $1.067^{* * *}$ \\
& $(0.149)$ & $(0.149)$ & $(0.131)$ & $(0.130)$ \\
Observations & & & & \\
R-squared & 56 & 56 & 56 & 56 \\
\hline
\end{tabular}

Note - All models are multivariate regression controlling for per capita income and Title index of 2015 . The outcome is the TomTom congestion measure defined as the extra time added by traffic on a basic car trip. Standard errors in parentheses. ${ }^{*} p<0.1 * * p<0.05 * * * p<0.01$ 
Table 7: Housing Loan Penetration, Title, and Transfer.

\begin{tabular}{|c|c|c|c|c|c|}
\hline & \begin{tabular}{l}
\multicolumn{1}{c}{$(1)$} \\
Housing Loan \\
Penetration
\end{tabular} & $\begin{array}{l}\qquad(2) \\
\text { Housing Loan } \\
\text { Penetration }\end{array}$ & $\begin{array}{l}\qquad(3) \\
\text { Housing Loan } \\
\text { Penetration }\end{array}$ & $\begin{array}{l}\quad \text { (4) } \\
\text { Housing Loan } \\
\text { Penetration, } \\
\text { Upper income } \\
\text { countries }\end{array}$ & $\begin{array}{l}\qquad(5) \\
\text { Housing Loan } \\
\text { Penetration, } \\
\text { rural }\end{array}$ \\
\hline Title & $\begin{array}{c}0.259 * * \\
(0.122)\end{array}$ & & $\begin{array}{c}0.114 \\
(0.135)\end{array}$ & $\begin{array}{c}0.152 \\
(0.176)\end{array}$ & $\begin{array}{l}0.0573 \\
(0.157)\end{array}$ \\
\hline Transfer & $\begin{array}{c}4.403^{* * *} \\
(0.613)\end{array}$ & $\begin{array}{c}4.766 * * * \\
(0.453)\end{array}$ & $\begin{array}{c}4.429 * * * \\
(0.603)\end{array}$ & $\begin{array}{c}10.08 * * * \\
(1.238)\end{array}$ & $\begin{array}{c}4.377^{* * *} \\
(0.701)\end{array}$ \\
\hline Log (GDP per capita) & & $\begin{array}{c}-0.946 * * * \\
(0.309)\end{array}$ & $\begin{array}{c}-0.811^{* *} \\
(0.348)\end{array}$ & $\begin{array}{c}-0.916 * * \\
(0.435)\end{array}$ & $\begin{array}{c}-0.994 * * \\
(0.404)\end{array}$ \\
\hline Constant & $\begin{array}{c}-28.95 * * * \\
(4.207)\end{array}$ & $\begin{array}{c}-28.76 * * * \\
(3.904)\end{array}$ & $\begin{array}{c}-27.49 * * * \\
(4.187)\end{array}$ & $\begin{array}{c}-84.76 * * * \\
(10.96)\end{array}$ & $\begin{array}{c}-26.68 * * * \\
(4.863)\end{array}$ \\
\hline Observations & 138 & 138 & 138 & 73 & 138 \\
\hline R-squared & 0.556 & 0.571 & 0.574 & 0.637 & 0.489 \\
\hline
\end{tabular}

Note: "Upper income countries" are defined as countries with above-average per capita GDP in 2017. Standard errors in parentheses. * $p<0.1 * * p<0.05 * * *$ $p<0.01$ 
Figure 1 - Correlation between Title and WJP expropriation risk.

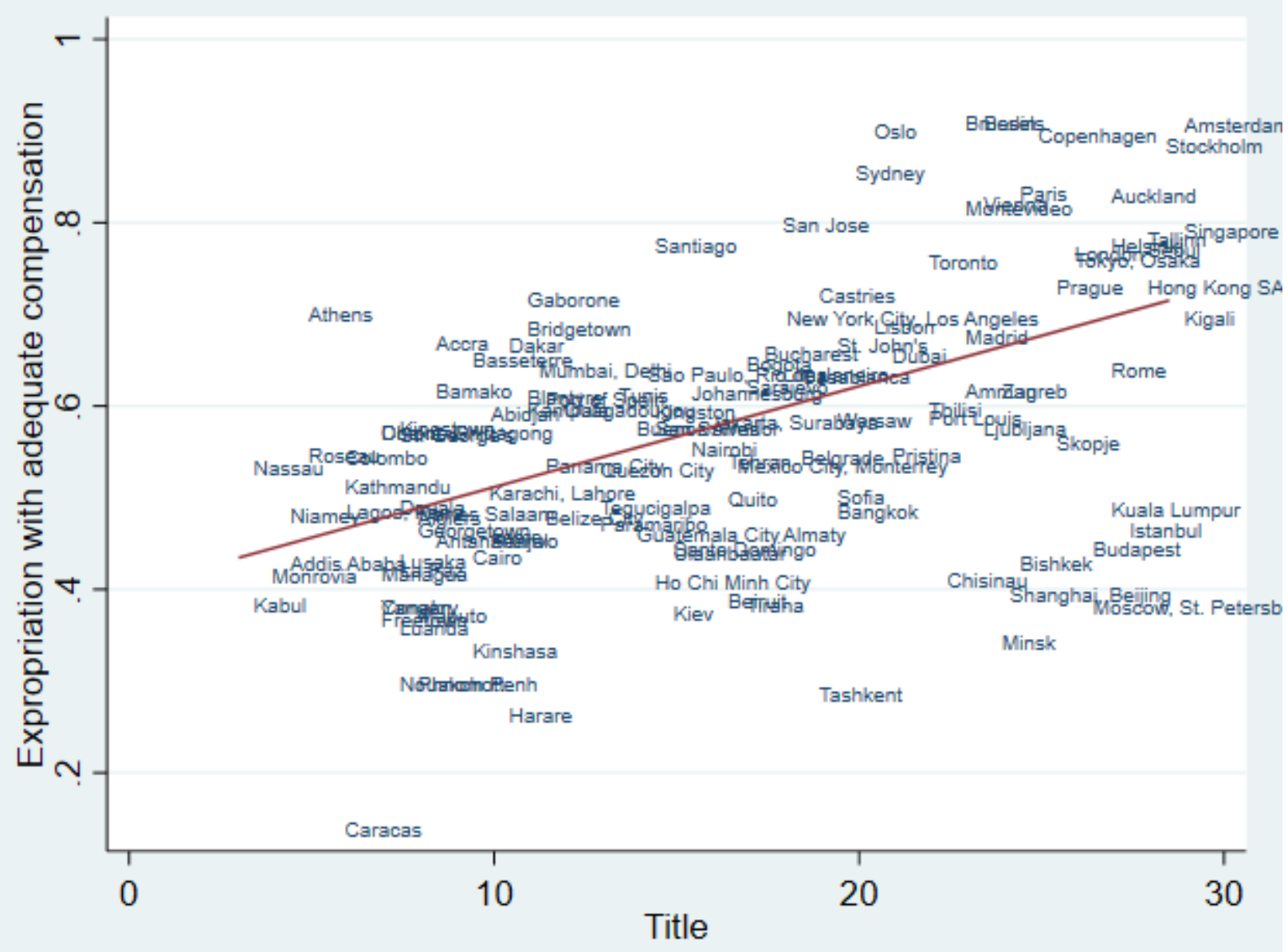


Figure 2-Title, by log(GDP) quintiles in 2015.

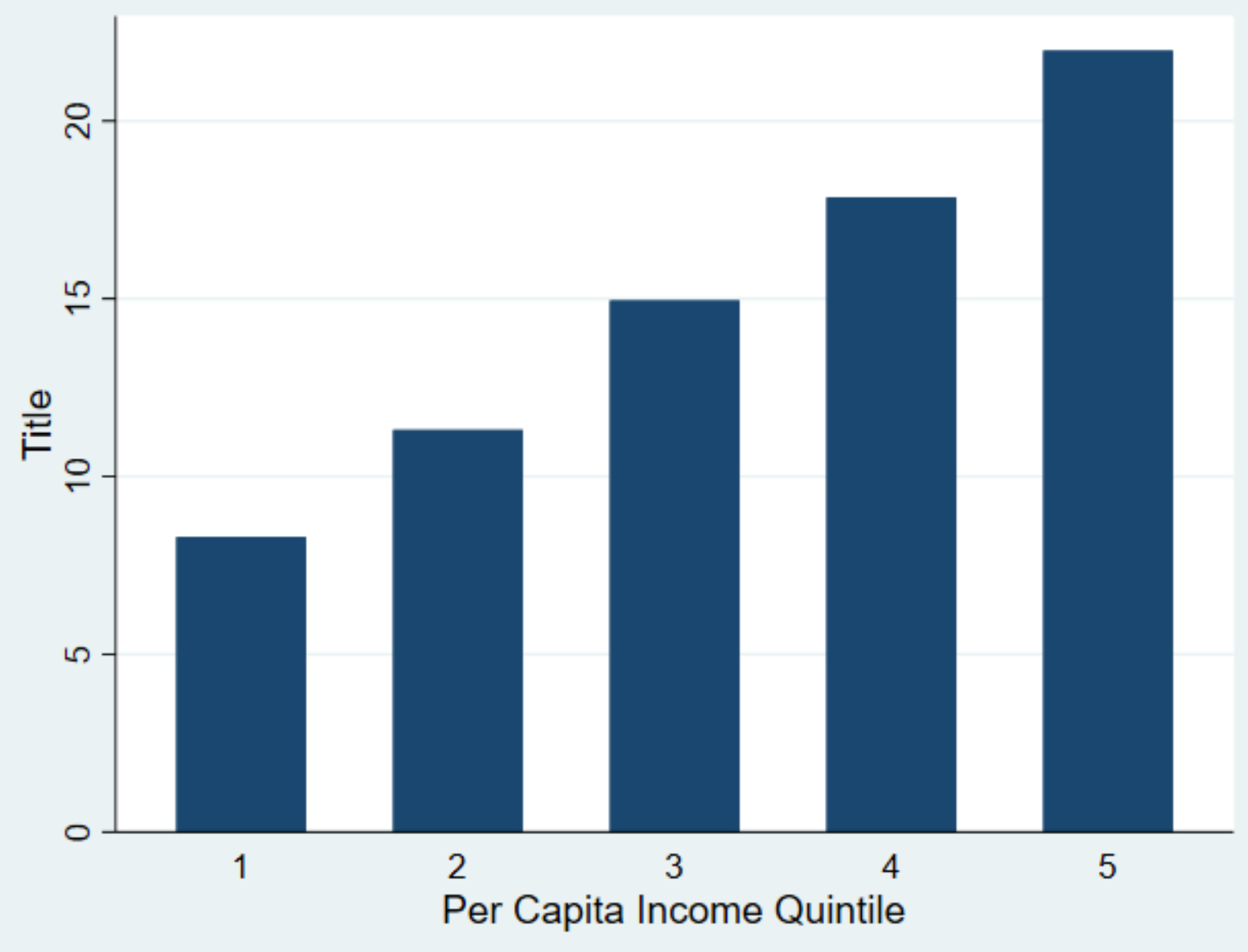


Figure 3 -Title and Transfer.

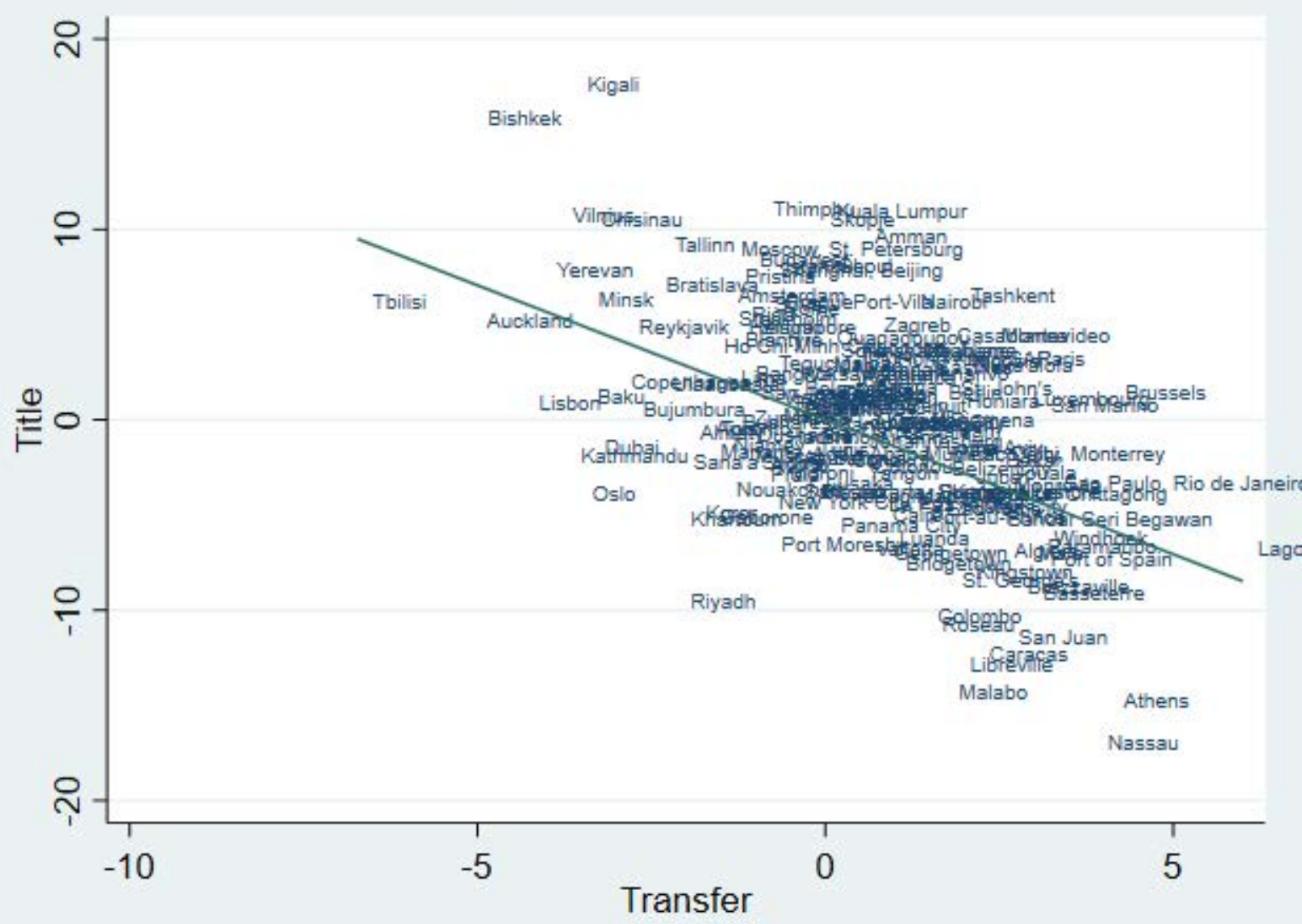

Note - Figure shows the partial correlation between Title and Transfer, controlling for GDP Per Capita. 
Figure 4 - Title, population density and distance from city center.

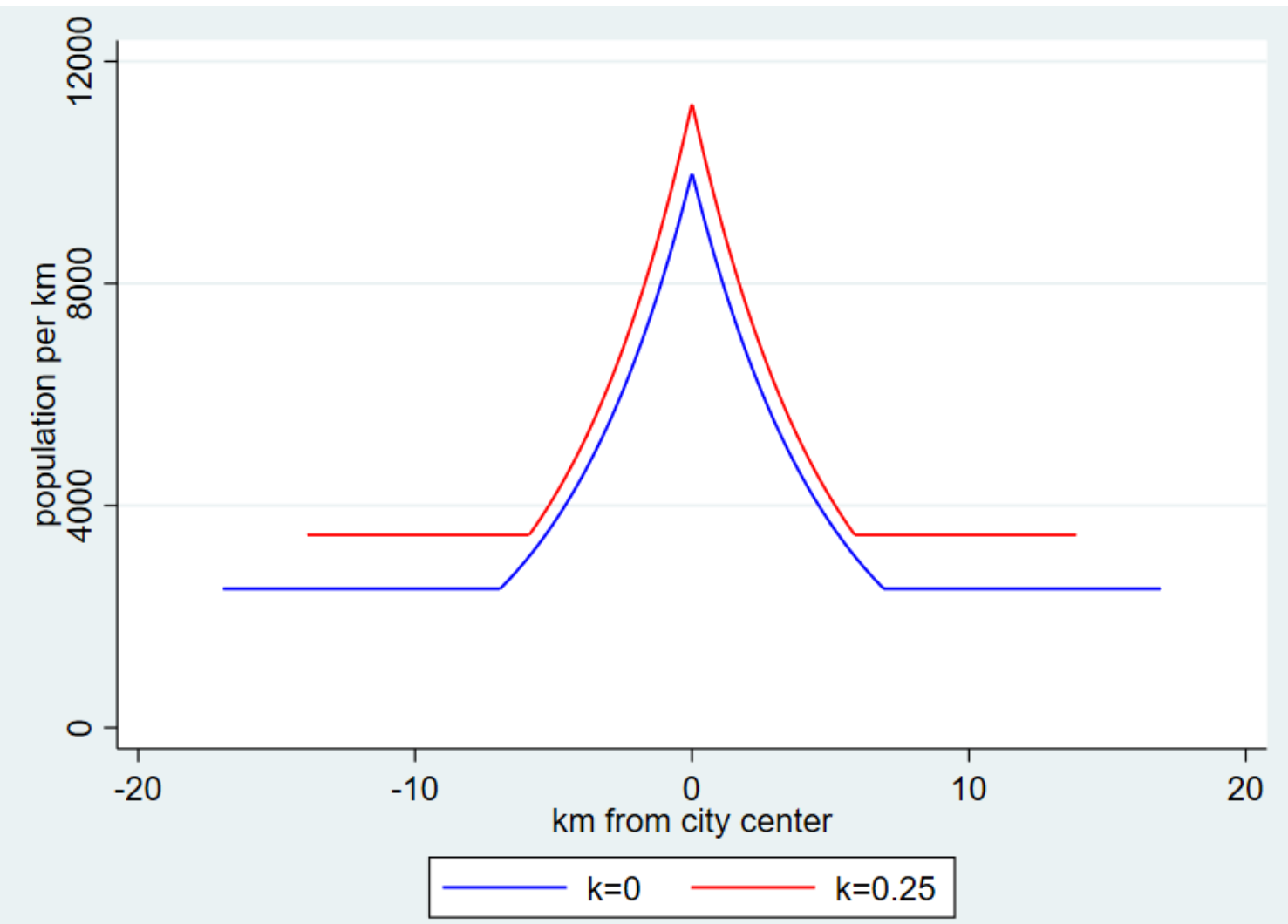


Figure 5 - Transfer, population density and distance from city center.

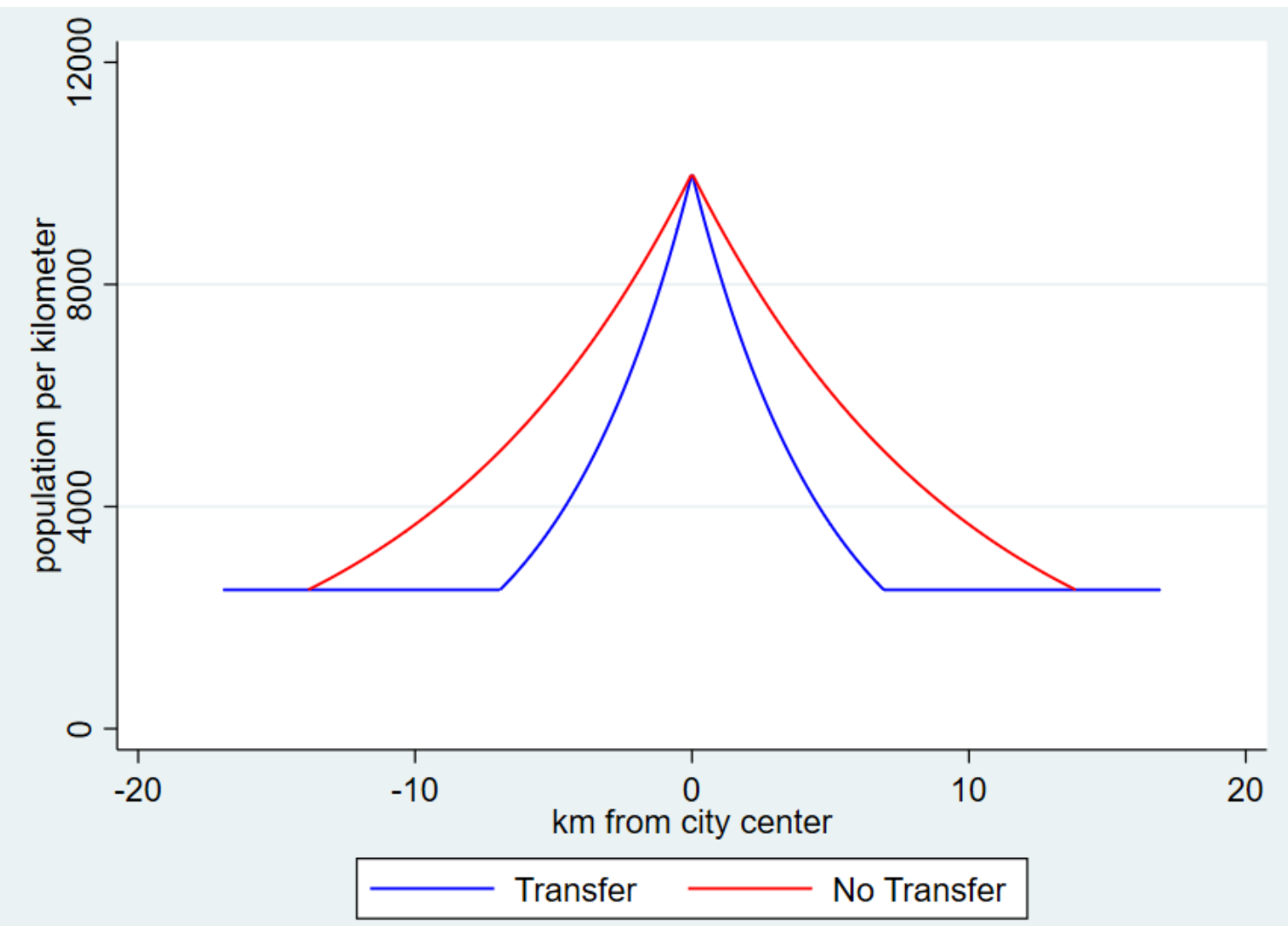


Figure 6 - Housing Loan Penetration and Title

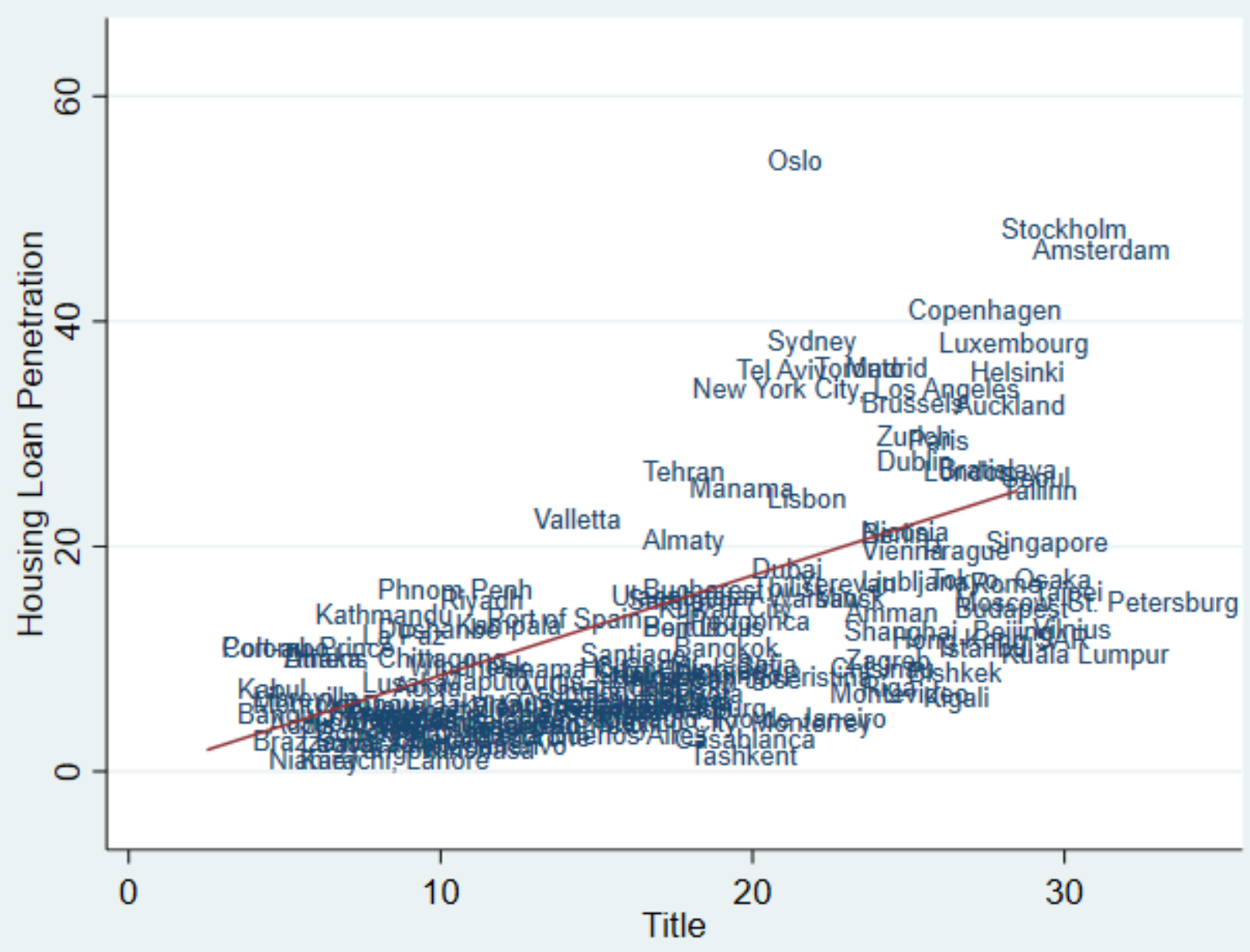


Figure 7 - Housing Loan Penetration and Transfer procedures

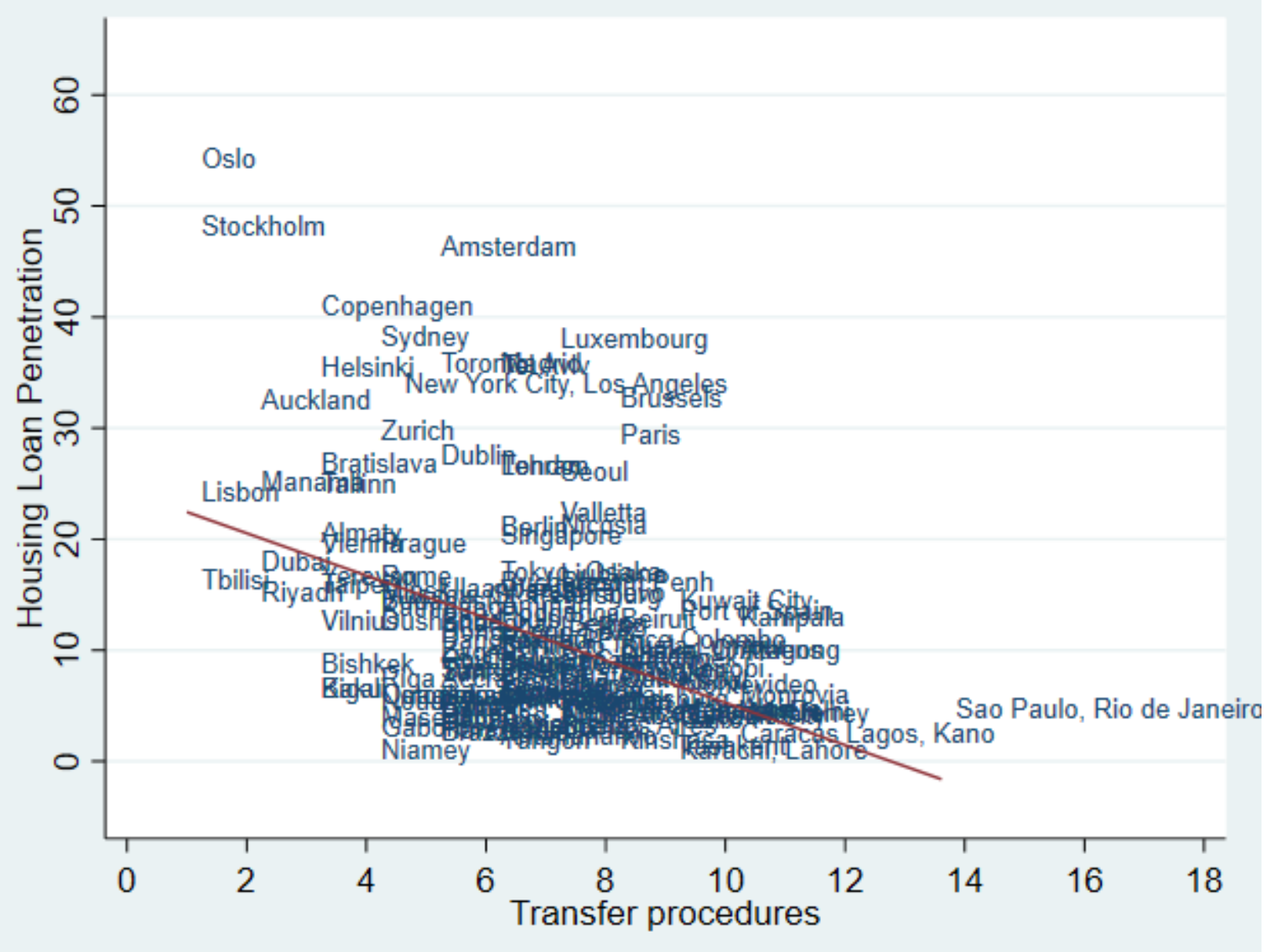


Figure 8 - Evolution of Title and Transfer over time, by 2004 quintiles of log(GDP per capita).

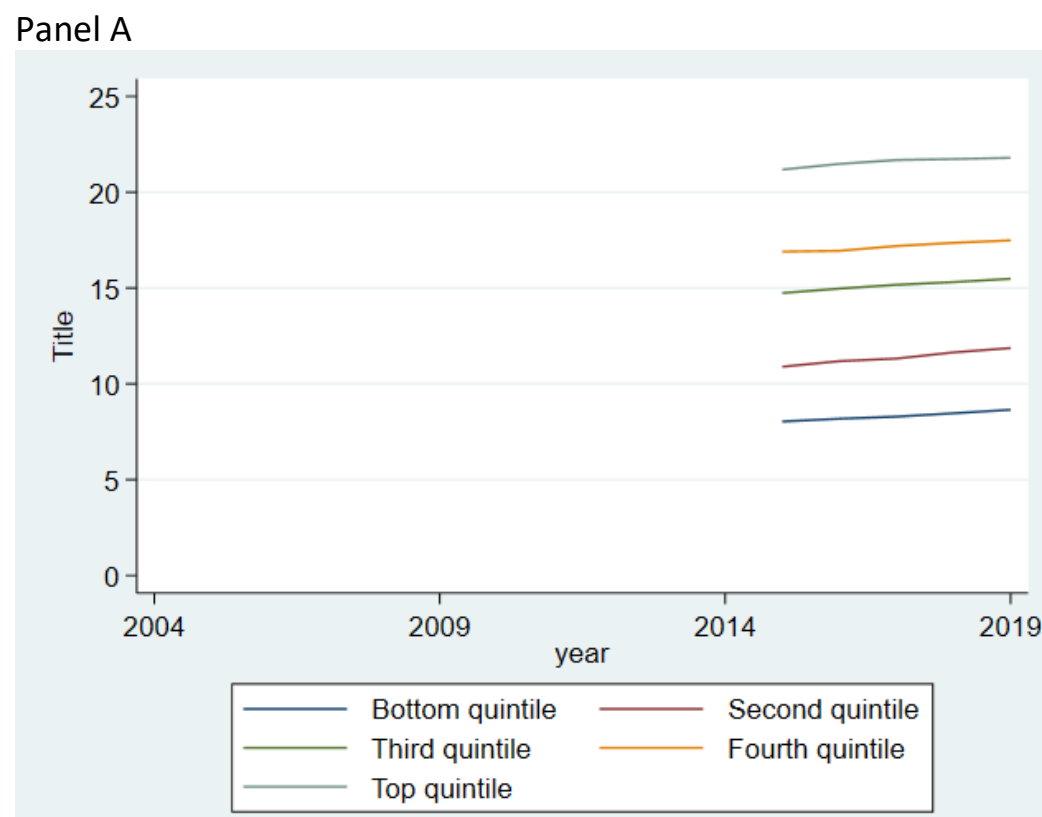

Panel B

Panel C
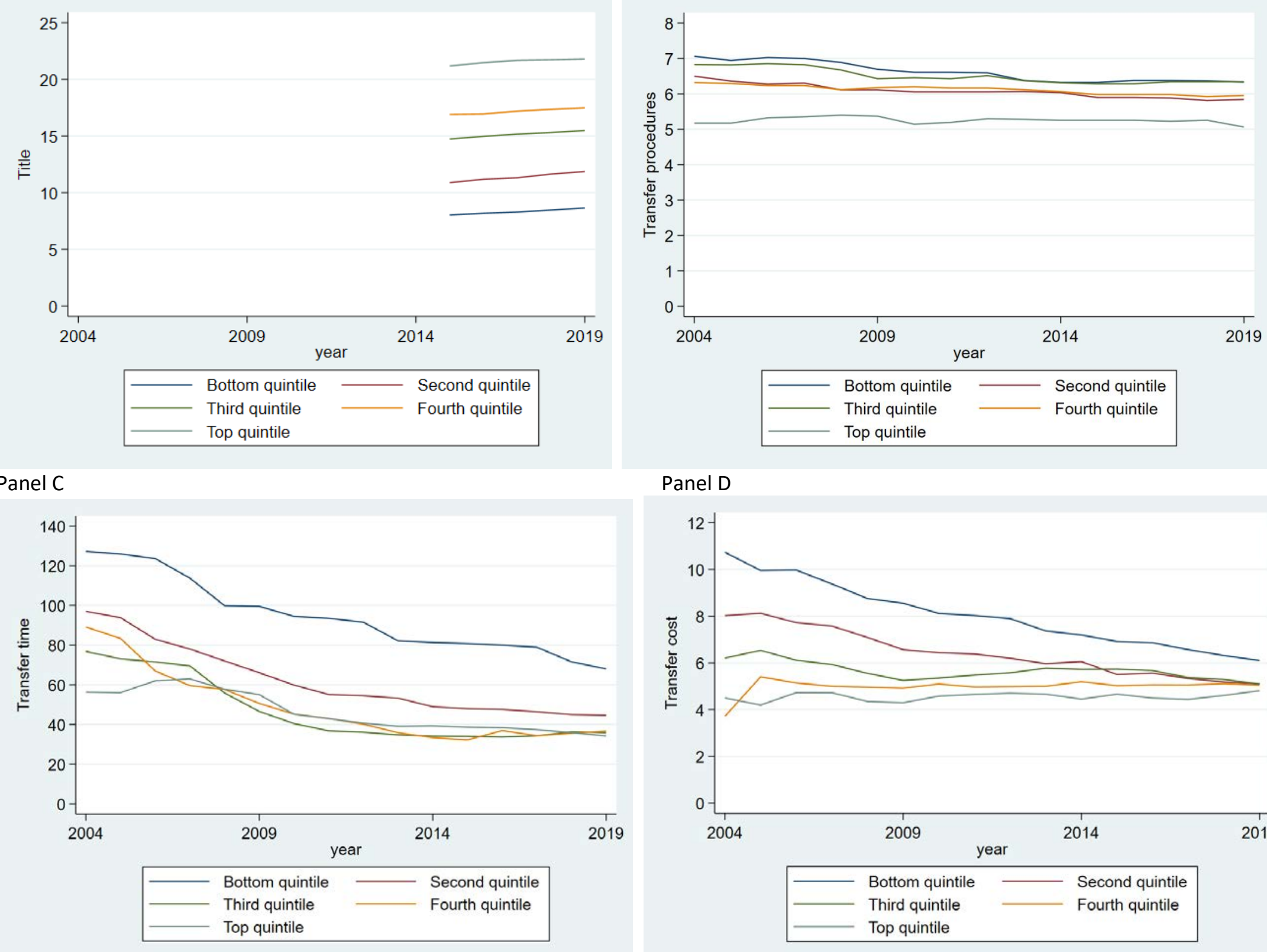

Panel D

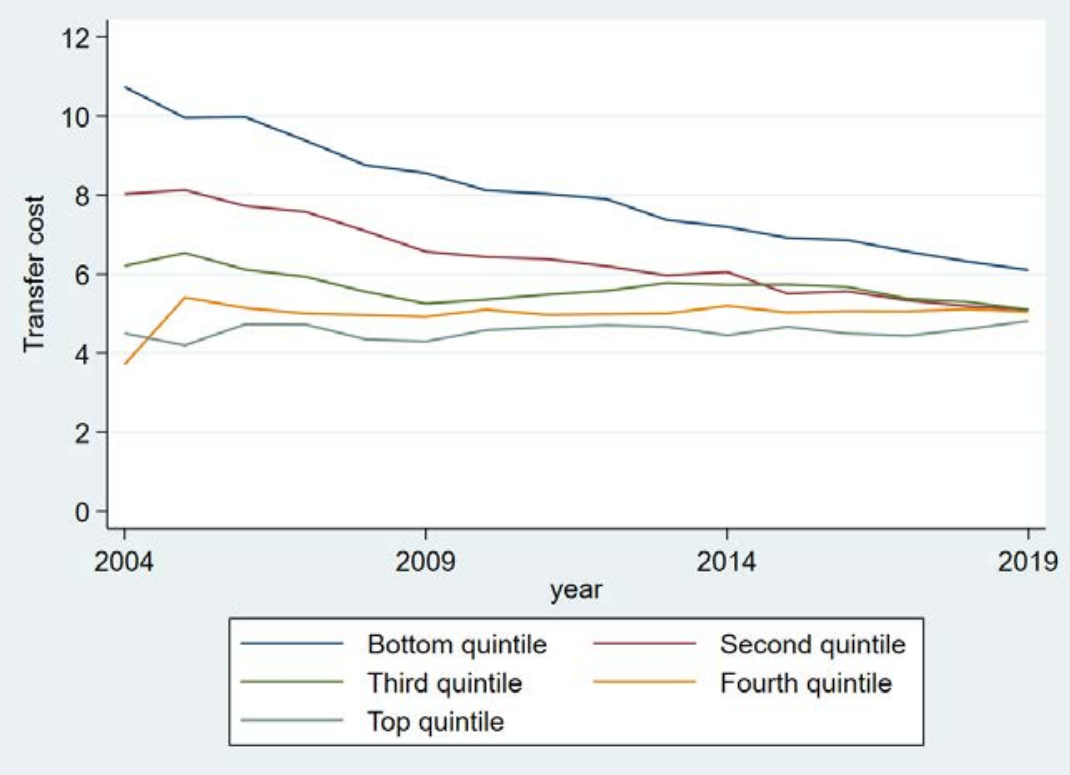




\section{World Bank - Registering Property Data}

The World Bank (WB) records the full sequence of procedures necessary for a limited liability company (the buyer) to purchase a property from another business (the seller) and to transfer the property title to the buyer's name so that the buyer can use the property for expanding its business, as collateral in taking out new loans or, if necessary, to sell the property to another business. It also measures the time (in calendar days) and cost (as a percentage of the property value) to complete each of these procedures. WB also measures the quality of the land administration system in each economy. If private sector entities were unable to register property transfers in a particular year, the economy receives a "no practice" mark on the procedures, time and cost indicators. A "no practice" economy receives a score of 0 on the quality of land administration index even if its legal framework includes provisions related to land administration. A more detailed description of the data is available on the World Bank website.

\section{Efficiency of transferring property}

As recorded by WB, the process of transferring property starts with obtaining the necessary documents, such as a recent copy of the seller's title if necessary and conducting due diligence as required. The transaction is considered complete when it is opposable to third parties and when the buyer can use the property for expanding his or her business, as collateral for a bank loan or resell it. Every procedure required by law or necessary in practice is included, whether it is the responsibility of the seller or the buyer or must be completed by a third party on their behalf. Local property lawyers, notaries and property registries provide information on procedures as well as the time and cost to complete each of them.

To make the data comparable across economies, several assumptions about the parties to the transaction, the property and the procedures are used.

The parties (buyer and seller):

- Are limited liability companies (or their legal equivalent).

- Are located in the periurban (that is, on the outskirts of the city but still within its official limits) area of the economy's largest business city. For 11 economies the data are also collected for the second largest business city.

- Are $100 \%$ domestically and privately owned.

- Perform general commercial activities.

The property:

- Has a value of 50 times income per capita, which equals the sale price.

- Is fully owned by the seller.

- Has no mortgages attached and has been under the same ownership for the past 10 years.

- Is registered in the land registry or cadastre, or both, and is free of title disputes.

- Is located in a periurban commercial zone (that is, on the outskirts of the city but still within its official limits), and no rezoning is required.

- Consists of land and a building. The land area is 557.4 square meters (6,000 square feet). A two-story warehouse of 929 square meters (10,000 square feet) is located on the land. The warehouse is 10 years old, is in good condition, has no heating system and complies with all safety standards, building codes and other legal requirements. The property, consisting of land and a building, will be transferred in its entirety. 
- Will not be subject to renovations or additional construction following the purchase.

- Has no trees, natural water sources, natural reserves or historical monuments of any kind.

- Will not be used for special purposes, and no special permits, such as for residential use, industrial plants, waste storage or certain types of agricultural activities, are required.

- Has no occupants, and no other party holds a legal interest in it.

\section{Quality of land administration}

The quality of land administration index is composed of five other indices: the reliability of infrastructure, transparency of information, geographic coverage, land dispute resolution and equal access to property rights. Data are collected for each economy's largest business city. For 11 economies the data are also collected for the second largest business city.

The quality of land administration index is the sum of the scores on the five indices. The index ranges from 0 to 30 with higher values indicating better quality of the land administration system.

\section{Reliability of infrastructure index}

The reliability of infrastructure index has six components:

1. In what format land title certificates are kept at the immovable property registry of the largest business city of the economy. A score of 2 is assigned if the majority of land title certificates are fully digital; 1 if scanned; 0 if kept in paper format.

2. Whether there is a comprehensive and functional electronic database for checking all encumbrances, caveats, charges or privileges affecting a registered property's encumbrances. A score of 1 is assigned if yes; 0 if no.

3. In what format cadastral plans are kept at the mapping agency of the largest business city of the economy. A score of 2 is assigned if the majority of cadastral plans are fully digital; 1 if scanned; 0 if kept in paper format.

4. Whether there is a geographic information system (a fully digital geographic representation of the land plot) an electronic database for recording boundaries, checking plans and providing cadastral information. A score of 1 is assigned if yes; 0 if no.

5. Whether the land ownership registry and mapping agency are linked. A score of 1 is assigned if information about land ownership and maps is kept in a single database or in linked databases; 0 if there is no connection between different databases.

6. How immovable property is identified. A score of 1 is assigned if both the immovable property registry and the mapping agency use the same identification number for properties; 0 if there are multiple identifiers.

\section{$\underline{\text { Transparency of information index }}$}

The transparency of information index has 10 components:

1. Whether information on land ownership is made publicly available. A score of 1 is assigned if information on land ownership is accessible by anyone; 0 if access is restricted.

2. Whether the list of documents required for completing all types of property transactions is made easily available to the public. A score of 0.5 is assigned if the list of documents is easily accessible online or on a public board; 0 if it is not made available to the public or if it can be obtained only in person.

3. Whether the fee schedule for completing all types of property transactions is made easily available to the public. A score of 0.5 is assigned if the fee schedule is easily accessible online or on a public board free of charge; 0 if it is not made available to the public or if it can be obtained only in person. 
4. Whether the immovable property agency formally specifies the time frame to deliver a legally binding document proving property ownership. A score of 0.5 is assigned if such service standard is accessible online or on a public board; 0 if it is not made available to the public or if it can be obtained only in person.

5. Whether there is a specific and independent mechanism for filing complaints about a problem that occurred at the agency in charge of immovable property registration. A score of 1 is assigned if there is a specific and independent mecha-nism for filing a complaint; 0 if there is only a general mechanism or no mechanism.

6. Whether there are publicly available official statistics tracking the number of transactions at the immovable property registration agency in the largest business city. A score of 0.5 is assigned if statistics are published about property transfers in the largest business city in the past calendar year at the latest on May 1st of the following year; 0 if no such statistics are made publicly available.

7. Whether maps of land plots are made publicly available. A score of 0.5 is assigned if cadastral plans are accessible by anyone; 0 if access is restricted.

8. Whether the fee schedule for accessing cadastral plans is made easily available to the public. A score of 0.5 is assigned if the fee schedule is easily accessible online or on a public board free of charge; 0 if it is not made available to the public or if it can be obtained only in person.

9. Whether the mapping agency formally specifies the time frame to deliver an updated cadastral plan. A score of 0.5 is assigned if the service standard is accessible online or on a public board; 0 if it is not made available to the public or if it can be obtained only in person.

10. Whether there is a specific and independent mechanism for filing complaints about a problem that occurred at the mapping agency. A score of 0.5 is assigned if there is a specific and independent mecha-nism for filing a complaint; 0 if there is only a general mechanism or no mechanism.

\section{$\underline{\text { Geographic coverage index }}$}

The geographic coverage index has four components:

1. How complete the coverage of the land registry is at the level of the largest business city. A score of 2 is assigned if all privately held land plots in the city are formally registered at the land registry; 0 if not.

2. How complete the coverage of the land registry is at the level of the economy. A score of 2 is assigned if all privately held land plots in the economy are formally registered at the land registry; 0 if not.

3. How complete the coverage of the mapping agency is at the level of the largest business city. A score of 2 is assigned if all privately held land plots in the city are mapped; 0 if not.

4. How complete the coverage of the mapping agency is at the level of the economy. A score of 2 is assigned if all privately held land plots in the economy are mapped; 0 if not.

\section{$\underline{\text { Land dispute resolution index }}$}

The land dispute resolution index assesses the legal framework for immovable property registration and the accessibility of dispute resolu-tion mechanisms. The index has eight components:

1. Whether the law requires that all property sale transactions be regis-tered at the immovable property registry to make them opposable to third parties. A score of 1.5 is assigned if yes; 0 if no.

2. Whether the formal system of immovable property registration is subject to a guarantee. A score of 0.5 is assigned if either a state or private guarantee over immovable property registration is required by law; 0 if no such guarantee is required.

3. Whether there is a specific, out-of-court compensation mechanism to cover for losses incurred by parties who engaged in good faith in a prop-erty transaction based on erroneous information certified by the immov-able property registry. A score of 0.5 is assigned if yes; 0 if no. 
4. Whether the legal system requires verification of the legal validity of the documents (such as the sales, transfer or conveyance deed) necessary for a property transaction. A score of 0.5 is assigned if there is a review of legal validity, either by the registrar or by a professional (such as a notary or a lawyer); 0 if there is no review.

5. Whether the legal system requires verification of the identity of the parties to a property transaction. A score of 0.5 is assigned if there is verification of identity, either by the registrar or by a professional (such as a notary or a lawyer); 0 if there is no verification.

6. Whether there is a national database to verify the accuracy of government-issued identity documents. A score of 1 is assigned if such a national database is available; 0 if not.

7. How much time it takes to obtain a decision from a court of first instance (without an appeal) in a standard land dispute between two local busi-nesses over tenure rights worth 50 times income per capita and located in the largest business city. A score of 3 is assigned if it takes less than one year; 2 if it takes between one and two years; 1 if it takes between two and three years; 0 if it takes more than three years.

8. Whether there are publicly avail-able statistics on the number of land disputes at the economy level in the first instance court. For the 11 economies where the data are also collected for the second largest business city, citylevel statistics are taken into account. A score of 0.5 is assigned if statistics are published about land disputes in the economy in the past calendar year; 0 if no such statistics are made publicly available.

Equal access to property rights index

The equal access to property rights index has two components:

1. Whether unmarried men and unmar-ried women have equal ownership rights to property. A score of -1 is assigned if there are unequal owner-ship rights to property; 0 if there is equality.

2. Whether married men and married women have equal ownership rights to property. A score of - 1 is assigned if there are unequal ownership rights to property; 0 if there is equality. 


\section{Online Appendix B}

Proofs:

Proof of Proposition 1: The model is symmetric, so exactly M/2 people will live in positive space and $\mathrm{M} / 2$ people will live in negative space. The paper who work at home will live on the urban edge. The individuals who commute will choose land to maximize: $\quad W-t d-(k+1) p(i) L+\alpha \ln (L)$, so that $(1+k) p(i) L=\alpha . \quad$ The non-commuters will maximize $\delta W-(k+1) p(i) L+\alpha \ln (L)$, At the urban edge, $r_{A}=p(i)$ and so density will equal $1 / L$ or $r_{A}(1+k) / \alpha$.

Individuals must be indifferent across locations, which implies that for commuters in positive space $-t=(1+k) p^{\prime}(i) L$, and the differential equation for $\mathrm{p}$ is: $\frac{p(i)}{p(i)}=-\frac{t}{\alpha}$.

If $\hat{p}$, denotes the maximum price at $\mathrm{i}=0$, then $p(i)=e^{-\frac{t}{\alpha}|i|} \hat{p}$, land consumption satisfies $L(i)=\frac{\alpha}{(1+k) \hat{p}} e^{\frac{t}{\alpha}|i|}$ and density satisfies $D(i)=\frac{(1+k) \hat{p}}{\alpha} e^{-\frac{t}{\alpha}|i|}$.

At the border of the commuting zone, which we denote as point $\mathrm{b}($ and $-\mathrm{b}), r_{A}=e^{-\frac{t}{\alpha} b} \hat{p}$ or $b=\frac{\alpha}{t} \ln \left(\frac{\hat{p}}{r_{A}}\right)$.

To close the model, we solve for $\hat{p}$, by noting that the quantity of commuters, $q M$, must live in the area bounded by $b$ and $-\mathrm{b}$, which implies $\frac{q M}{2}=\int_{i=0}^{b} \frac{(1+k) \hat{p}}{\alpha} e^{-\frac{t}{\alpha} i} d i=\frac{(1+k) \hat{p}}{\alpha} \cdot \frac{\alpha}{t}\left(1-e^{-\frac{t}{\alpha} b}\right)=(1+k) \frac{\hat{p}-r_{A}}{t}$, so that $\frac{q M t}{2(1+k)}+r_{A}=\hat{p}$ and $b=$ $\frac{\alpha}{t} \ln \left(\frac{2(1+k) r_{A}+q M t}{2(1+k) r_{A}}\right)$. The total expanse of the city is $\frac{2 \alpha}{t} \ln \left(\frac{2(1+k) r_{A}+q M t}{2(1+k) r_{A}}\right)+\frac{\alpha(1-q) M}{r_{A}(1+k)}$ and so total density is $\frac{2 \alpha}{t M} \ln \left(\frac{2(1+k) r_{A}+q M t}{2(1+k) r_{A}}\right)+\frac{\alpha(1-q)}{r_{A}(1+k)}$

The average commute length for commuters satisfies

$$
\frac{2 \hat{p}(1+k)}{\alpha q M} \int_{i=0}^{b} e^{-\frac{t}{\alpha} i} i d i=\frac{2 \hat{p}(1+k)}{\alpha q M} \frac{\alpha}{t}\left(\frac{\alpha}{t}-e^{-\frac{t}{\alpha} b}\left(\frac{\alpha}{t}+b\right)\right)=\frac{\alpha}{t}\left(1-\frac{2 r_{A}(1+k)}{q M t} \ln \left(1+\frac{q M t}{2 r_{A}(1+k)}\right)\right)
$$


The average commute length for the whole city is that quantity times q. Differentiation shows that this is declining with k.

Proof of Corollary 1: A slum dweller is defined as an individual living at a density level of $d_{S}$ or higher. If $\frac{r_{A}(1+k)}{\alpha}>d_{S}$ or $k>\frac{\alpha d_{S}-r_{A}}{r_{A}}$, then the residents of the city's edge (and everyone else as well) lives as slum level densities.

At the city center, density equals $\frac{(1+k) r_{A}}{\alpha}+\frac{q M t}{2 \alpha}$ and if $k<\frac{\alpha d_{S}-.5 q M t-r_{A}}{r_{A}}$, then density at the city center will lie below slum levels and no one will live in a slum.

If $\frac{\alpha d_{S}-r_{A}}{r_{A}}>k>\frac{\alpha d_{S}-.5 q M t-r_{A}}{r_{A}}$, then people will live in slums if and only if $\frac{q M t+2 r_{A}(1+k)}{2 \alpha} e^{-\frac{t}{\alpha}|i|}>d_{S}$, or $\frac{\alpha}{t} \ln \left(\frac{q M t+2 r_{A}(1+k)}{2 \alpha d_{S}}\right)>|i|$. The number of urbanities who live that close to the city center equals $2 \int_{i=0}^{\frac{\alpha}{t} \ln \left(\frac{q M t+2 r_{A}(1+k)}{2 \alpha d_{S}}\right)} \frac{q M t+2 r_{A}(1+k)}{2 \alpha} e^{-\frac{t}{\alpha} i} d i=q M-\frac{2\left(\alpha d_{S}-r_{A}(1+k)\right)}{t}$. The share of urbanites living in slums equals $q-$ $\frac{2\left(\alpha d_{S}-r_{A}(1+k)\right)}{t M}$, which is monontonically increasing in $\mathrm{k}$ and equals $\mathrm{q}$ when $\frac{\alpha d_{S^{-}} r_{A}}{r_{A}}=k$ and 0 when $k=\frac{\alpha d_{S^{-}} .5 q M t-r_{A}}{r_{A}}$.

Proof of Proposition 1': In a classic open city model, welfare in the city equals welfare elsewhere, which is denoted $\underline{U}$.

Define $Z$ as the constant which satisfies the equation $W-\alpha+\alpha \ln (\alpha)-\alpha \ln (Z)=\underline{U}$. As the spatial equilibrium requires that $\left.W-\alpha+\alpha \ln (\alpha)-\alpha \ln \left((1+k) r_{A}+.5 q M t\right)\right)=\underline{U}$, we know that $(1+k) r_{A}+.5 q M t=Z$ (hence $\left.(1+k) r_{A}<Z\right)$ and $M=\frac{2 Z-2(1+k) r_{A}}{q t}$, and so city population is shrinking with $\mathrm{k}$.

All of proposition 1 continues to hold, but we can now substitute for the endogenously determined value of M. Density is the inverse of $\frac{2 \alpha}{t M(k)} \ln \left(1+\frac{q M(k) t}{2(1+k) r_{A}}\right)+\frac{\alpha(1-q)}{r_{A}(1+k)}$ or $\frac{\alpha q}{Z-(1+k) r_{A}} \ln \left(\frac{Z}{(1+k) r_{A}}\right)+\frac{\alpha(1-q)}{r_{A}(1+k)}$. The derivative of this with respect to $k$ is $\frac{\alpha q r_{A}}{\left(Z-(1+k) r_{A}\right)^{2}}\left(\ln \left(\frac{Z}{(1+k) r_{A}}\right)+1-\frac{Z}{(1+k) r_{A}}\right)-\frac{\alpha(1-q)}{r_{A}(1+k)^{2}}$. As $\mathrm{X}>1+\ln (\mathrm{X})$, for all $\mathrm{X}>1, \ln \left(\frac{Z}{(1+k) r_{A}}\right)<\frac{Z}{(1+k) r_{A}}-$ 1 , this is always negative, and so overall density is rising with $\mathrm{k}$. 
The average commute distance equals $\frac{\alpha q}{t}-\frac{r_{A}(1+k) \alpha q}{t\left(Z-(1+k) r_{A}\right)} \ln \left(\frac{Z}{(1+k) r_{A}}\right)$ and the derivative of this with respect to $k$ equals $\frac{\alpha q r_{A}^{2}(1+k)}{t\left(Z-(1+k) r_{A}\right)^{2}}\left(\frac{\mathrm{Z}}{(1+k) r_{A}}-1-\frac{\mathrm{Z}}{(1+k) r_{A}} \ln \left(\frac{Z}{(1+k) r_{A}}\right)\right)$, which is always negative.

Proof of Proposition 2: The model is symmetric, so exactly M/2 people will live in positive space and commute and M/2 people will live in negative space. Everyone has a probability " $q$ " of commuting and 1-q of not commuting. At any location, individuals will choose land to maximize: $\quad W(q+(1-q) \delta)-t q d-(k+1) p(i) L+\alpha \ln (L)$, so that $(1+$

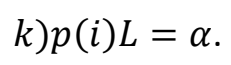

Individuals must be indifferent across locations, which implies that for commuters in positive space $-q t=(1+$ $k) p^{\prime}(i) L$, and the differential equation for $p$ is: $\frac{p \prime(i)}{p(i)}=-\frac{t q}{\alpha}$.

If $\hat{p}$, denotes the maximum price at $\mathrm{i}=0$, then $p(i)=e^{-\frac{t q}{\alpha}|i|} \hat{p}$, land consumption satisfies $L(i)=\frac{\alpha}{(1+k) \hat{p}} e^{\frac{q t}{\alpha}|i|}$ and density satisfies $D(i)=\frac{(1+k) \hat{p}}{\alpha} e^{-\frac{q t}{\alpha}|i|}$.

At the border of the city, which we denote as point $z$ (and $-z), r_{A}=e^{-\frac{t q}{\alpha} z} \hat{p}$ or $z=\frac{\alpha}{t q} \ln \left(\frac{\hat{p}}{r_{A}}\right)$.

To close the model, we solve for $\hat{p}$, by noting that the quantity of city residents, $M$, must live in the area bounded by $z$ and $-z$, which implies $\frac{M}{2}=\int_{i=0}^{Z} \frac{(1+k) \hat{p}}{\alpha} e^{-\frac{t q}{\alpha} i} d i=\frac{(1+k) \hat{p}}{\alpha} \cdot \frac{\alpha}{t q}\left(1-e^{-\frac{t q}{\alpha} Z}\right)=(1+k) \frac{\hat{p}-r_{A}}{t q}$, so that $\frac{q M t}{2(1+k)}+r_{A}=\hat{p}$ and $z=$ $\frac{\alpha}{t q} \ln \left(\frac{2(1+k) r_{A}+q M t}{2(1+k) r_{A}}\right) . \quad$ The total expanse of the city is $\frac{2 \alpha}{t q} \ln \left(\frac{2(1+k) r_{A}+q M t}{2(1+k) r_{A}}\right)$ and so total density is $\frac{2 \alpha}{t q M} \ln \left(\frac{2(1+k) r_{A}+q M t}{2(1+k) r_{A}}\right)$

The average commute length for commuters satisfies

$$
\frac{2 \hat{p}(1+k)}{\alpha M} \int_{i=0}^{z} e^{-\frac{q t}{\alpha} i} i d i=\frac{2 \hat{p}(1+k)}{\alpha M} \frac{\alpha}{q t}\left(\frac{\alpha}{q t}-e^{-\frac{q t}{\alpha} z}\left(\frac{\alpha}{q t}+z\right)\right)=\frac{\alpha}{q t}\left(1-\frac{2 r_{A}(1+k)}{q M t} \ln \left(1+\frac{q M t}{2 r_{A}(1+k)}\right)\right)
$$

This equals 1/q times average commute in Proposition 1. 